Review

\title{
Putative biomarkers for cervical cancer: SNVs, methylation and expression profiles
}

\author{
Maria de Fátima Senra Cardoso ${ }^{\mathrm{a}, *}$, Carlos Henrique Madeiros Castelletti ${ }^{\mathrm{a}, \mathrm{b}}$, \\ José Luiz de Lima-Filho ${ }^{\mathrm{c}, \mathrm{d}}$, Danyelly Bruneska Gondim Martins ${ }^{\mathrm{a}, \mathrm{d}}$, \\ José António Couto Teixeira ${ }^{\mathrm{c}, \mathrm{e}}$ \\ ${ }^{a}$ Molecular Prospection and Bioinformatics Group (ProspecMol), Laboratory of Immunopathology Keizo Asami (LIKA), Federal University of Pernambuco \\ (UFPE), Av. Prof. Moraes Rego s/n, Recife - PE, 50670-901, Brazil \\ ${ }^{\mathrm{b}}$ Agronomic Institute of Pernambuco (IPA), Av. General San Martin 1371, Bongi, Recife - PE, 50761-000, Brazil \\ ${ }^{\mathrm{c}}$ Laboratory of Immunopathology Keizo Asami (LIKA), Federal University of Pernambuco (UFPE), Av. Prof. Moraes Rego s/n, Recife - PE, 50670-901, Brazil \\ d Biochemistry Department, Federal University of Pernambuco (UFPE), Av. Prof. Moraes Rego s/n, Recife - PE, 50670-901, Brazil \\ e Department of Biological Engineering, University of Minho (UM), Campus de Gualtar, 4710-057 Braga, Portugal
}

\section{A R T I C L E I N F O}

\section{Article history:}

Received 30 January 2017

Received in revised form 28 June 2017

Accepted 29 June 2017

Available online 30 June 2017

\section{Keywords:}

Clinical markers

Genetic panel

Prognostic factors

Therapeutics

\section{A B S T R A C T}

Cervical cancer is primarily caused by Human papillomavirus (HPV) infection, but other factors such as smoking habits, co-infections and genetic background, can also contribute to its development. Although this cancer is avoidable, it is the fourth most frequent type of cancer in females worldwide and can only be treated with chemotherapy and radical surgery. There is a need for biomarkers that will enable early diagnosis and targeted therapy for this type of cancer. Therefore, a systems biology pipeline was applied in order to identify potential biomarkers for cervical cancer, which show significant reports in three molecular aspects: DNA sequence variants, DNA methylation pattern and alterations in mRNA/protein expression levels. CDH1, CDKN2A, RB1 and TP53 genes were selected as putative biomarkers, being involved in metastasis, cell cycle regulation and tumour suppression. Other ten genes (CDH13, FHIT, PTEN, MLH1, TP73, CDKN1A, CACNA2D2, TERT, WIF1, APC) seemed to play a role in cervical cancer, but the lack of studies prevented their inclusion as possible biomarkers. Our results highlight the importance of these genes. However, further studies should be performed to elucidate the impact of DNA sequence variants and/or epigenetic deregulation and altered expression of these genes in cervical carcinogenesis and their potential as biomarkers for cervical cancer diagnosis and prognosis.

(c) 2017 Elsevier B.V. All rights reserved.

\section{Contents}

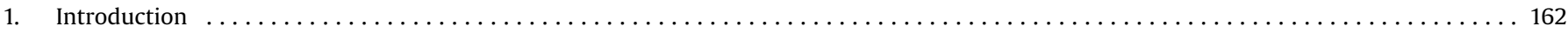

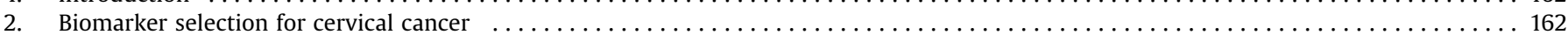

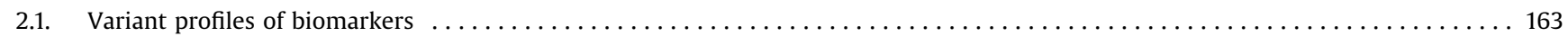

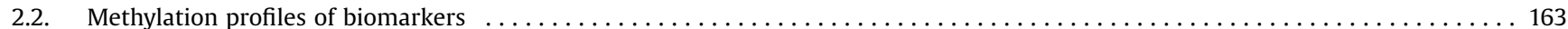

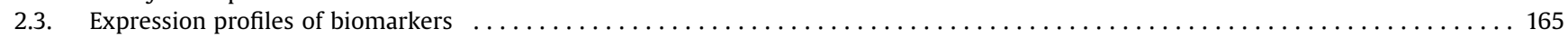

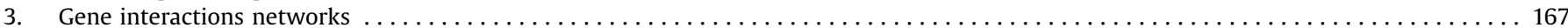

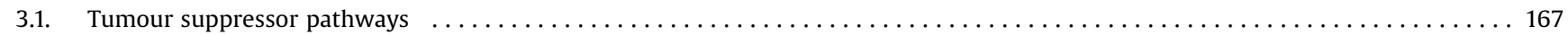

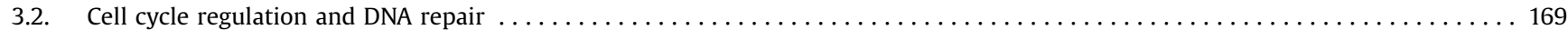

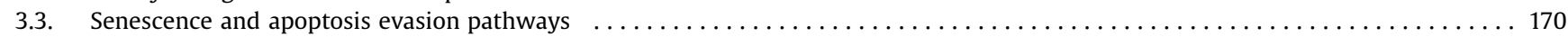

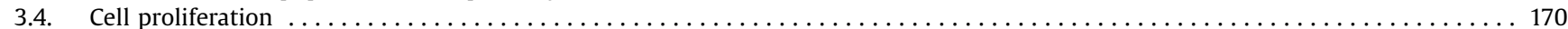

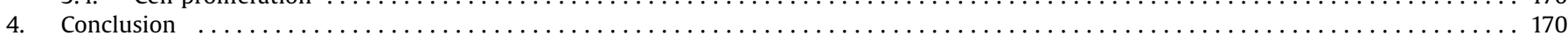

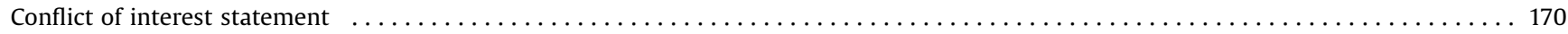

\footnotetext{
* Corresponding author.

E-mail address: mcardoso@prospecmol.org (M.d.F.S. Cardoso).
} 


\section{Introduction}

Worldwide, there are over 527,000 new cases of cervical cancer each year, qualifying it as the fourth most frequent type of cancer among women. It is responsible for approximately 265,700 deaths per year, with the large majority occurring in less developed countries [1]. Human papillomavirus (HPV) infection is the main etiological factor for the development of cervical cancer but other aspects, such as age, smoking oral contraceptives and parity, can also contribute to its development [2].

Most HPV infections are transient and asymptomatic and the majority of HPV infections, including those with high-risk genotypes, get cleared or become undetectable within two years $[3,4]$. The Pap smear test is the gold standard for cervical cancer prevention, although it has low sensitivity and a high frequency of false negatives. Visual inspection with acetic acid is used as a complementary method of evaluation, but only after a positive Pap smear result [5].

The occurrence of HPV infection is related to the secretion of molecules by the innate immune system that are able to recognize the presence of HPV. These molecules show higher expression levels in the endocervical specimens infected with HPV16, assisting in avoiding the viral infection and blocking the escape of the virion from the endocytic vesicles [6,7]. However, HPV is still able to avoid the activation of the immune response by escaping from antigen presentation and downregulating pro-inflammatory signalling [8]. Additionally, the genetic background of the patient can influence the development of the disease and can be associated with different outcomes. This perspective has emphasized the importance of studying variations within the DNA sequence, alterations in epigenetic modifications and deregulation in gene expression in order to determine genetic markers [9].

These findings pave the major steps towards personalized medicine, a tool to provide more reliable approaches for diagnosis and improve prognosis. Some molecular panels have been developed for breast and colorectal cancer [10,11], but none are available for cervical cancer. This study aims to identify the main genes associated with cervical cancer and their role in carcinogenesis, thus highlighting potential biomarkers for early diagnosis, prognosis and targeted therapy.

\section{Biomarker selection for cervical cancer}

A systems biology pipeline was established to search the Metacore $^{\mathrm{TM}}$ database for genes with variations in their DNA sequence, alterations in methylation patterns and changes in mRNA/protein expression patterns in cervical cancer samples. After that, the obtained results were cross-referenced with previously obtained data. At this point, a list of diseases affected by each molecular aspect of the selected genes in Metacore ${ }^{\mathrm{TM}}$ was collected.

Manual data mining of scientific studies using the scientific search engines PubMed and ScienceDirect was conducted to identify the genes that showed significant molecular alterations in cervical cancer, leading to the identification of a total of 2980 candidate genes. Single nucleotide variation (SNV) occurrence was studied in 2487 genes, while only 54 genes were evaluated for methylation patterns changes. The mRNA/protein levels were evaluated for 2464 genes, but the reports rarely correlated with the role of SNVs and epigenetic modifications in these genes (Fig. 1).

A cross-reference analysis was performed, allowing the identification of genes reported with the following three aspects in cervical cancer: DNA sequence variation, alteration in methylation or changes in mRNA/protein levels. A total of 14 genes were selected, among them nine were tumour suppressors genes (TP53, RB1, TP73, APC, PTEN, FHIT, CDH1, CDH13, WIF1); two cell cycle regulator genes (CDKN1A, CDKN2A); one gene related to mismatch repair (MLH1); one oncogene (TERT); and one gene encoding a calcium channel (CACNA2D2). This approach was able to identify genes that are known to be affected by HPV infection, such as TP53 and RB1, and are highly studied in cervical cancer, as well as others relatively new to this field, such as FHIT and CDH13. This set of genes was already studied in 366 diseases and, for didactic purposes, it was divided into 17 categories according to the organ/ system affected. The cancer category consisted of 180 cancer types (Fig. 2).

Integration of the data for SNVs, DNA methylation and mRNA/ protein expression for each gene showed different correlation levels to different diseases (Fig. 3). Although these 14 genes were studied in cervical cancer, only CDH1, CDKN2A, RB1 and TP53 were reported as statistical significant in the literature for all the three

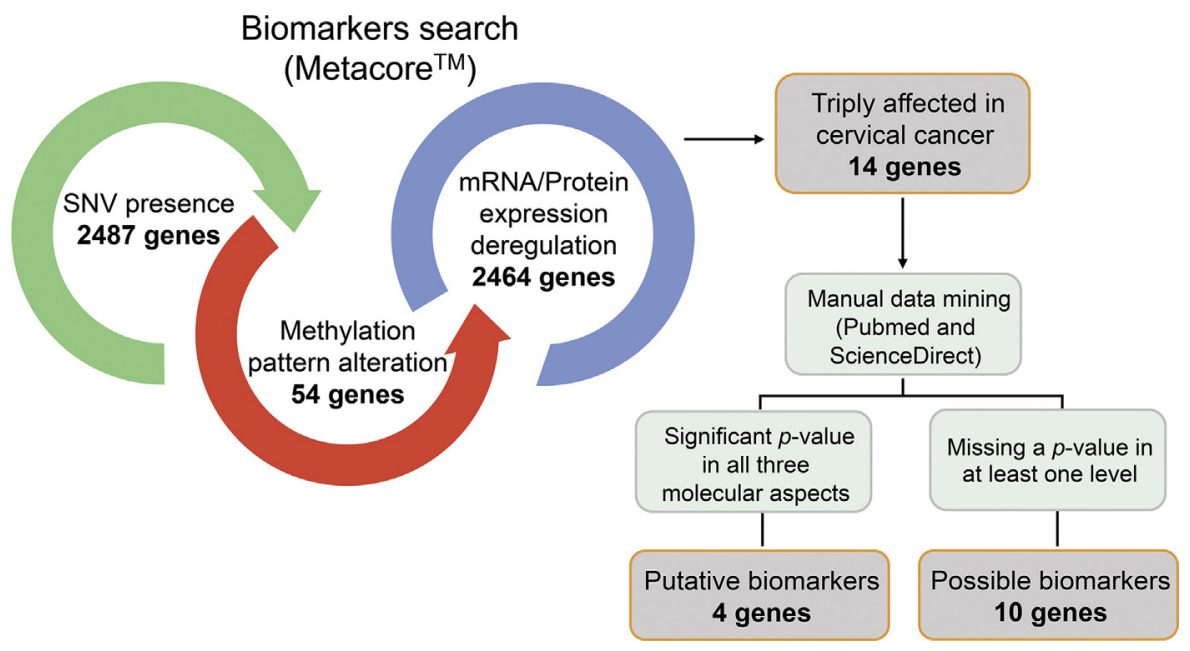

Fig. 1. Gene selection through the systems biology pipeline. 


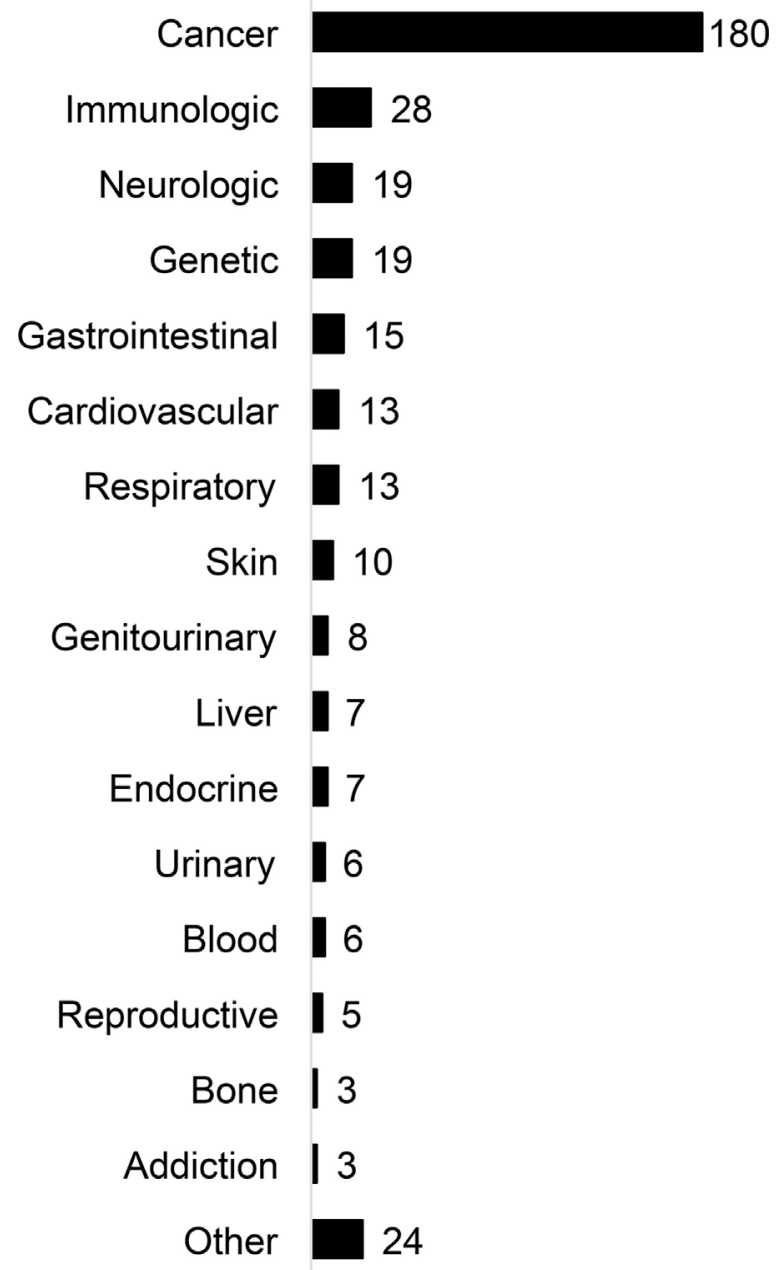

No. Diseases

Fig. 2. Distribution of diseases observed according to the 17 Categories.

molecular aspects (Table 1), thus granting them the status of putative biomarkers.

TP53 was the most cited gene with 838 references reported in all the 17 diseases categories and 282 different diseases studied, while the CDH1 gene showed only 20 cross-References.

\subsection{Variant profiles of biomarkers}

Together, the CDH1, CDKN2A, RB1 and TP53 SNVs showed 494 cross-references in 79 cancer types (Fig. 4A). The list of SNVs in cervical cancer in relation to their molecular characteristics, the categories reported and the number of diseases associated with them is presented in Supplementary data, Table 1.

The CDH1 gene product, E-cadherin, is present on the membrane of epithelial cells. E-cadherin is responsible for cell adhesion, but it is also involved in transducing chemical signals inside cells, controlling cell maturation and movement, and regulating the activity of certain genes. E-cadherin also acts as a tumour suppressor [34], but only one SNV in its gene has been studied in cervical cancer. The CDH1 c. ${ }^{*} 54 \mathrm{C}>\mathrm{T}$ SNV is located in the $3^{\prime}$-untranslated region ( $3^{\prime} \mathrm{UTR}$ ), and it was identified in 280 cervical cancer samples. The $\mathrm{T}$ allele was shown to be protective against the development of cervical cancer $(p=0.01)$, with a lower frequency in stage III patients [12]. This SNV was also studied in 4 other cancer types (breast, oesophageal, non-small-cell lung and stomach cancers), showing significance in oesophageal carcinoma [35], and non-small-cell lung cancer [12].

The retinoblastoma 1 (RB1) gene, a tumour suppressor gene, encodes the $\mathrm{pRB}$ protein, which regulates cell growth and interacts with other proteins to influence cell survival, apoptosis and differentiation [36]. The RB1 c.1814+394G > A SNV located in the intronic region has only been studied in cervical cancer. A study on 150 samples from an Indian population showed that individuals with the AA genotype had a 1.77-fold higher risk for development of cervical cancer $(\mathrm{p}=0.026)$ [20].

Cyclin-dependent kinase inhibitor 2A (CDKN2A) encodes two different proteins, $\mathrm{p} 14^{\mathrm{ARF}}$ and $\mathrm{p} 16^{\mathrm{INK} 4}$, due to alternative splicing of exon $1 \beta$ and exon $1 \alpha$, respectively [37], and both are able to induce cell cycle arrest [38]. CDKN2A has 12 SNVs studied in cervical cancer out of which c. ${ }^{*} 29 \mathrm{G}>\mathrm{C}$ located in the $3^{\prime} \mathrm{UTR}$ is the most reported. A study in 150 cervical cancer patients and 150 agematched women with no malignancy demonstrated a protective effect of the $G$ allele against cervical cancer $(p=0.0001)$. The same study showed that c. ${ }^{*} 69 \mathrm{C}>\mathrm{T}$, also located in $3^{\prime} \mathrm{UTR}$, was significantly found in the patients carrying the T allele (CT or TT genotypes $)(p=0.0004)$, although the allelic frequency evaluation did not show such association ( $p=0.072)$ [20]. On the contrary, no significance was observed for any of these SNVs in a study of 92 abnormal cervical samples infected with HPV16 and 32 normal samples [39], indicating that even though CDKN2A is not involved in the viral infection and proliferation, it may be important for the neoplastic process.

The tumour suppressor 53 (TP53) gene encodes for a tumour suppressor protein that plays a critical role in determining whether the DNA will be repaired or if the damaged cell will undergo apoptosis [40]. This is the most studied gene in cancer (79 cancer types) with 40 SNVs evaluated. The missense variant of TP53 c. $215 C>$ G, corresponding to codon P72R, is the most studied SNV among the cardiovascular, endocrine, gastrointestinal and genetic categories. In a Chinese study in 323 cervical cancer patients and 568 normal samples, it was found that the CG genotype is a risk factor for the development of cervical cancer $(p=0.02)$ [29], and another study found that the genotype GG is associated with cervical cancer [30]. Despite that, this TP53 variant was not found to be associated with 43 squamous cell carcinoma (SCC) and 67 cervical intraepithelial neoplasia (CIN) samples in another study [24]. The frequency of TP53 SNVs was not only associated with different populations, as it was more common in Asian populations, but also related to different cervical cancer types, with the higher variant frequency associated with adenocarcinoma (AC) than SCC [40].

\subsection{Methylation profiles of biomarkers}

All four genes showed hypermethylation of the promoter regions in cervical cancer, having also been studied in the other 56 different types of cancer (Fig. 4B). CDKN2A methylation was studied in 51 cancer types, while TP53 was studied in just seven types of cancer, namely cervical cancer, breast cancer, hepatocellular carcinoma, multiple myeloma, non-small-cell lung cancer, ovarian cancer and stomach cancer.

Although TP53 is the most studied gene in various cancer types, little is known about its role in cervical cancer. Only one study with 125 cervical cancer samples and 100 control samples describing the methylation of the TP53 gene in association with cancer risk $(\mathrm{p}<0.05)$ has been reported [31]. Hypermethylation of TP53 had already been reported in other diseases such as hepatocellular carcinoma in relation to the reduced expression of TP53 [41], as well as in breast cancer [42] and ovarian cancer [43], thereby reinforcing the importance of its alteration in carcinogenesis. 


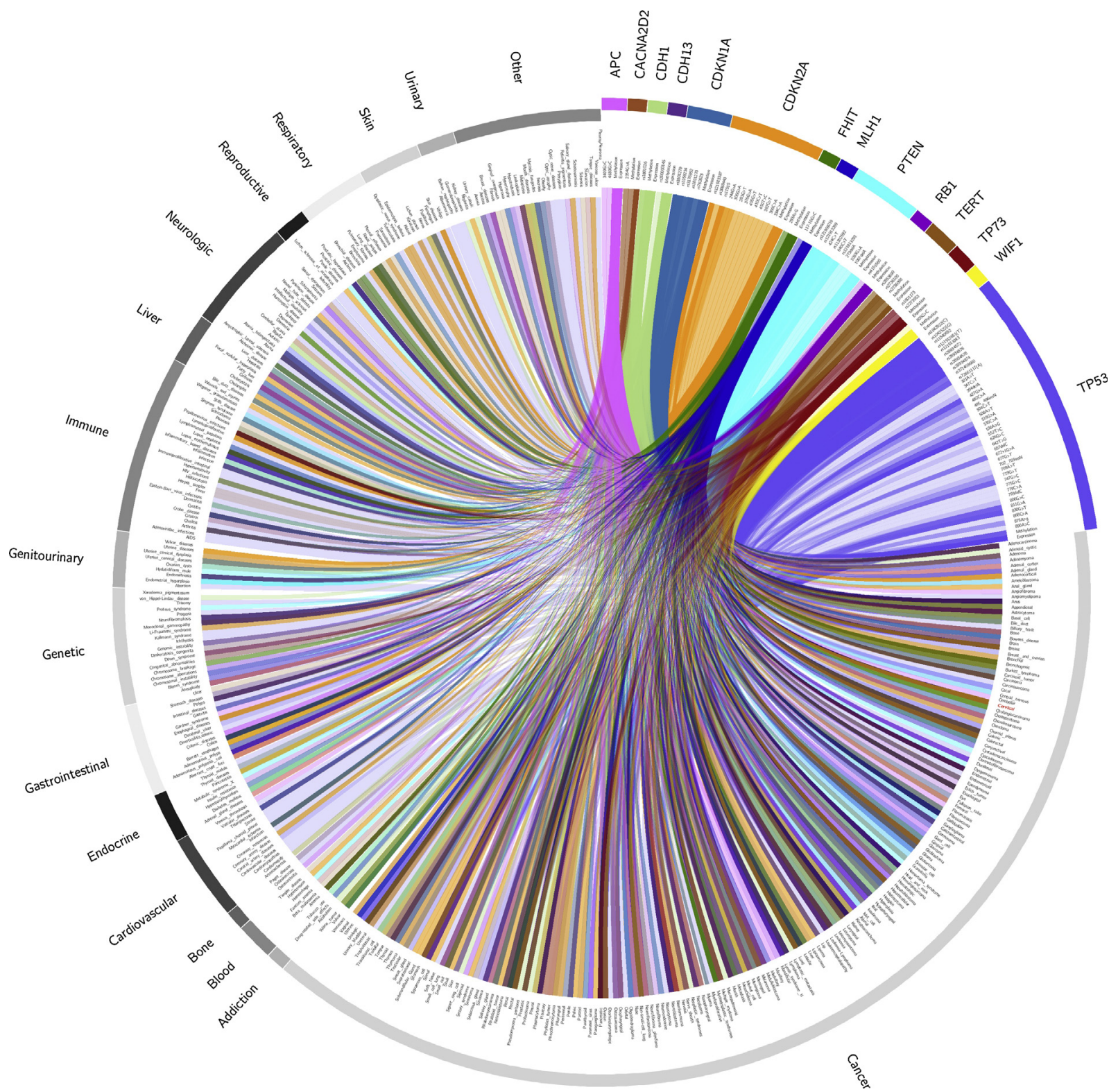

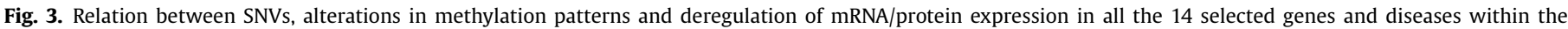

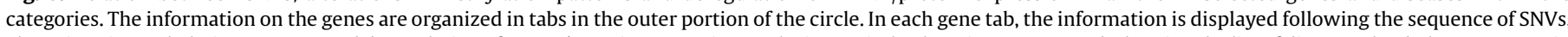

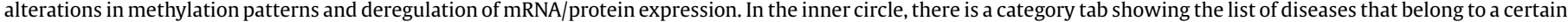

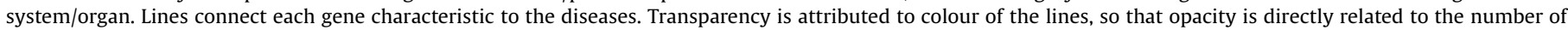
diseases affected by each molecular aspect.

A study investigating the methylation status of CDKN2A in 78 cervical cancer samples showed significant hypermethylation in cervical cancer in comparison with the normal cervix $(p<0.0001)$, thus also correlating the methylation status of CDKN2A to the stage of cancer [21]. The hypermethylation status of CDKN2A indeed increased with the progression from low- to high-grade lesions of the cervix $(p<0.05)$ [22], which could explain the reduced expression of $\mathrm{p} 16^{\mathrm{INK} 4}$ in the high-grade cervical lesions [44]. However, there are conflicting results for CDKN2A methylation thus questioning the significance of the methylation status being observed in the cancer and normal samples [45].

The hypermethylation of the RB1 promoter was studied in 50 samples from patients with prior lesions in the cervix and 15 cervix samples from patients with normal cytology and colposcopy. The results demonstrated an increasing degree of methylation with the severity of the lesion ( $p=0.009)$ as well as an association with HPV infection $(p=0.042)[28]$. However, these results are still controversial [31].

The $\mathrm{CDH} 1$ gene showed increasing methylation levels from the normal to dysplastic to invasive cervical cancer samples $(\mathrm{p}<0.05)$ [15]. This gene was also hypermethylated in several SCC and CIN3 samples [14]. A study in 82 cervical cancer samples investigating 16 genes, including DAPK, RARB, FHIT, and TIMP3, demonstrated that $\mathrm{CDH} 1$ is the most hypermethylated gene and is associated with the cancer stage $(\mathrm{p}=0.0005)$ [16]. Together with $\mathrm{CDH} 13(\mathrm{H}-$ cadherin), $\mathrm{CDH} 1$ hypermethylation was also associated with worse disease prognosis $(\mathrm{p}<0.05)$ [17], indicating its participation in cervical cancer. It was associated with a 92.8-fold risk of relapse $(p=0.005)$ and a 7.8 -fold risk of death $(p=0.001)$ [13]. In HeLa cells, the hypermethylation of the $\mathrm{CDH} 1$ promoter region was associated with the absence of gene expression. However, the treatment with the green tea polyphenol (-)-epigallocatechin-3-gallate could 
Table 1

List of genes and their molecular aspects reported in cervical cancer showing experimental design and $p$-value.

\begin{tabular}{|c|c|c|c|c|c|c|c|}
\hline Gene & $\begin{array}{l}\text { Molecular } \\
\text { aspect }\end{array}$ & Samples & Sample characterization & Sample type; Country & Analysis & p-value & Ref. \\
\hline \multirow[t]{8}{*}{$\mathrm{CDH} 1$} & c. $+54 \mathrm{C}>\mathrm{T}$ & $\begin{array}{l}280 \mathrm{SG} \\
330 \mathrm{C}\end{array}$ & 280 CC +330 normal cytology & Blood; China & PCR-RFLP & 0.01 & [12] \\
\hline & Methylation & $\begin{array}{l}49 \text { SG } \\
40 \mathrm{C}\end{array}$ & $49 \mathrm{CC}+40$ non-malignant gynaecological diseases & Serum; Austria & MPCR & 0.001 & [13] \\
\hline & & $\begin{array}{l}49 \text { SG } \\
22 \mathrm{C}\end{array}$ & 49 ISCC +22 normal cytology & FFPE + LBC; USA & PS & $<0.05$ & [14] \\
\hline & & $\begin{array}{l}62 \mathrm{SG} \\
38 \mathrm{C}\end{array}$ & $35 \mathrm{CC}+27$ SIL +38 normal cytology & Fresh Tissue; India & MSP & $<0.05$ & [15] \\
\hline & & $\begin{array}{l}121 \mathrm{SG} \\
8 \mathrm{C}\end{array}$ & $77 \mathrm{SCC}+5 \mathrm{AC}+39 \mathrm{CIN}+8$ normal cytology & $\begin{array}{l}\text { Fresh tissue, FFPE, LBC; } \\
\text { Colombia + Germany }\end{array}$ & MSP & 0.0005 & [16] \\
\hline & & 93 SG & $84 \mathrm{SCC}+9 \mathrm{AC}$ & Serum; Austria & MPCR & $<0.05$ & [17] \\
\hline & Expression & $\begin{array}{l}100 \mathrm{SG} \\
6 \mathrm{C}\end{array}$ & 70 CC +11 CIN3 + 19 CIN $1 / 2+6$ Normal & TMA; China & IHC & $<0.05$ & [18] \\
\hline & & $\begin{array}{l}135 \mathrm{SG} \\
55 \mathrm{C}\end{array}$ & 135 SCC +55 normal cytology & FFPE; China & $\mathrm{IHC}$ & $<0.05$ & [19] \\
\hline \multirow[t]{8}{*}{ CDKN2A } & c. ${ }^{*} 29 \mathrm{G}>\mathrm{C}$ & $\begin{array}{l}150 \mathrm{SG} \\
150 \mathrm{C}\end{array}$ & 150 CC + 150 normal cytology & Fresh Tissue + LBC; India & PCR-RFLP & 0.0001 & [20] \\
\hline & Methylation & $\begin{array}{l}78 \mathrm{SG} \\
24 \mathrm{C}\end{array}$ & $66 \mathrm{SCC}+12 \mathrm{AC}+24$ normal cytology & Fresh frozen tissue; South Korea & MSP & $<0.0001$ & [21] \\
\hline & & $68 \mathrm{SG}$ & $23 \mathrm{ISCC}+10 \mathrm{CIN} 3+8 \mathrm{CIN} 2+27 \mathrm{CIN} 1$ & Fresh frozen tissue + LBC; USA & $\mathrm{Ila}+\mathrm{HTa}+\mathrm{TBS}$ & $<0.05$ & [22] \\
\hline & Expression & 166 SG & $16 \mathrm{SCC}+2 \mathrm{AC}+98 \mathrm{HSIL}+50 \mathrm{LSIL}$ & FFPE; Brazil & $\mathrm{IHC}$ & $<0.001$ & [23] \\
\hline & & $\begin{array}{l}110 \mathrm{SG} \\
20 \mathrm{C}\end{array}$ & $\begin{array}{l}43 \text { ISCC + } 38 \text { CIN3 + } 11 \text { CIN2 + } 18 \text { CIN1 }+20 \text { normal } \\
\text { cytology }\end{array}$ & Fresh frozen tissue; Egypt & $\mathrm{IHC}$ & 0.01 & [24] \\
\hline & & $\begin{array}{l}132 \mathrm{SG} \\
17 \mathrm{C}\end{array}$ & $\begin{array}{l}20 \mathrm{ISCC}+20 \mathrm{HSIL}+42 \mathrm{LSIL}+50 \text { ASCUS + } 17 \text { normal } \\
\text { cytology }\end{array}$ & LBC; China & ICC + qRT-PCR & $<0.05$ & [25] \\
\hline & & $\begin{array}{l}200 \mathrm{SG} \\
30 \mathrm{C}\end{array}$ & $30 \mathrm{SCC}+50 \mathrm{CIN} 3+50 \mathrm{CIN} 2+50 \mathrm{CIN} 1$ & FFPE; China & $\mathrm{IHC}$ & 0.046 & [26] \\
\hline & & $\begin{array}{l}45 \mathrm{SG} \\
5 \mathrm{CL} \\
48 \mathrm{C}\end{array}$ & $5 \mathrm{CL}+45$ HSIL +48 normal cytology & LBC; Germany & qRT-PCR & $<0.001$ & [27] \\
\hline \multirow[t]{3}{*}{ RB1 } & $\begin{array}{l}\text { c. } 1814+394 G> \\
\text { A }\end{array}$ & $\begin{array}{l}150 \mathrm{SG} \\
150 \mathrm{C}\end{array}$ & 150 CC + 150 normal cytology & Fresh tissue + LBC; India & PCR-RFLP & 0.02 & [20] \\
\hline & Methylation & $\begin{array}{l}50 \mathrm{SG} \\
15 \mathrm{C}\end{array}$ & 18 CC + 15 HSIL + 17 LSIL + 15 normal cytology & Fresh tissue + LBC; Brazil & MSP & 0.009 & [28] \\
\hline & Expression & $\begin{array}{l}110 \mathrm{SG} \\
20 \mathrm{C}\end{array}$ & $\begin{array}{l}43 \text { ISCC + } 38 \text { CIN3 + } 11 \text { CIN2 + } 18 \text { CIN1 + } 20 \text { normal } \\
\text { cytology }\end{array}$ & Fresh frozen tissue; Egypt & $\mathrm{IHC}$ & $<0.05$ & [24] \\
\hline \multirow[t]{6}{*}{ TP53 } & c. $215 C>G$ & $\begin{array}{l}328 \mathrm{SG} \\
568 \mathrm{C}\end{array}$ & 328 CC +568 normal cytology & Blood; China & PCR-RFLP & 0.02 & [29] \\
\hline & & $\begin{array}{l}114 \mathrm{SG} \\
200 \mathrm{C}\end{array}$ & $103 \mathrm{AC}+9 \mathrm{SCC}+200$ cancer-free cervix & Blood.; China & PCR-RFLP & 0.009 & [30] \\
\hline & Methylation & $\begin{array}{l}125 \mathrm{SG} \\
100 \mathrm{C}\end{array}$ & $125 \mathrm{CC}+100$ healthy females & Fresh tissue + Blood; India & MSP & $<0.05$ & [31] \\
\hline & Expression & $\begin{array}{l}110 \mathrm{SG} \\
20 \mathrm{C}\end{array}$ & $\begin{array}{l}43 \text { ISCC + } 38 \text { CIN3 + } 11 \text { CIN2 + } 18 \text { CIN1 + } 20 \text { normal } \\
\text { cytology }\end{array}$ & Fresh frozen tissue; Egypt & $\mathrm{IHC}$ & 0.01 & [24] \\
\hline & & $125 \mathrm{SG}$ & $92 \mathrm{SCC}+33 \mathrm{AC}$ & FFPE, China & $\mathrm{IHC}$ & $<0.05$ & [32] \\
\hline & & $\begin{array}{l}60 \mathrm{SG} \\
60 \mathrm{C}\end{array}$ & $60 \mathrm{CC}+60$ normal tumour-adjacent regions & FFPE, China & $\mathrm{IHC}$ & $<0.05$ & [33] \\
\hline
\end{tabular}

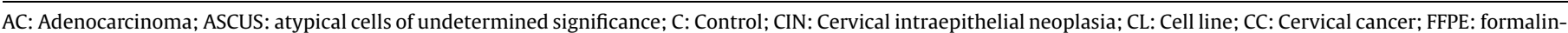

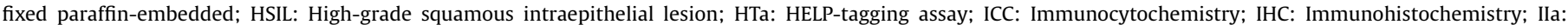

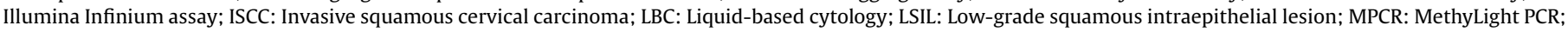

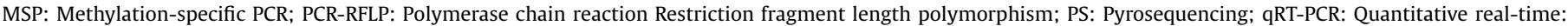

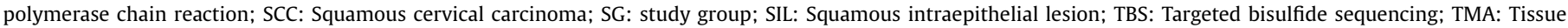
microarray paraffin-embedded

revert this effect [46], which suggests that the $\mathrm{CDH} 1$ gene can be a relevant biomarker for targeted therapy.

\subsection{Expression profiles of biomarkers}

Our cross-referencing results showed that a total of 394 mRNA/ protein expression were associated with 169 cancer types, and studies in 33 cancer types demonstrated the deregulation of expression for all the genes (Fig. 4C). TP53 and CDKN2A, which were found to be upregulated in cervical cancer, are the most studied genes in cancer, while CDH1 and RB1 were found to be downregulated.

Deregulation of TP53 protein expression was the most reported among the four biomarkers selected and was affected in 144 cancer types. During cervical infection with high-risk HPV, the production of the oncoprotein E6 targets the p53 protein for proteosomal degradation [47], resulting in lower levels of p53 in the cervical cancer cells. Therefore, low levels of p53 have been found in the cells infected with HPV16 and producing oncoprotein E6 [48]. Another study in 125 patients showed the presence of p53 in 56.8\% of the cases, with higher levels in AC compared to SCC ( $p<0.05)$. The level of $\mathrm{p} 53$ was also associated with lymph node metastasis $(\mathrm{p}<0.05)$ [32]. A study in 60 cervical cancer samples and 60 controls also showed higher p53 levels in the cervical cancer samples than the normal samples $(\mathrm{p}<0.05)$, and the elevated $\mathrm{p} 53$ level was also associated with lymph node metastasis $(\mathrm{p}<0.05)$ [33]. This identifies p53 as a robust prognostic biomarker in cervical cancer, even though its regulatory mechanism needs to be elucidated further.

Although CDKN2A encodes for both $\mathrm{p} 14^{\mathrm{ARF}}$ and $\mathrm{p} 16^{\mathrm{INK} 4}$, most studies have focused on the latter. The expression of $\mathrm{p} 16^{\text {INK4 }}$ has been evaluated in 114 different types of cancer, and a study in 50 


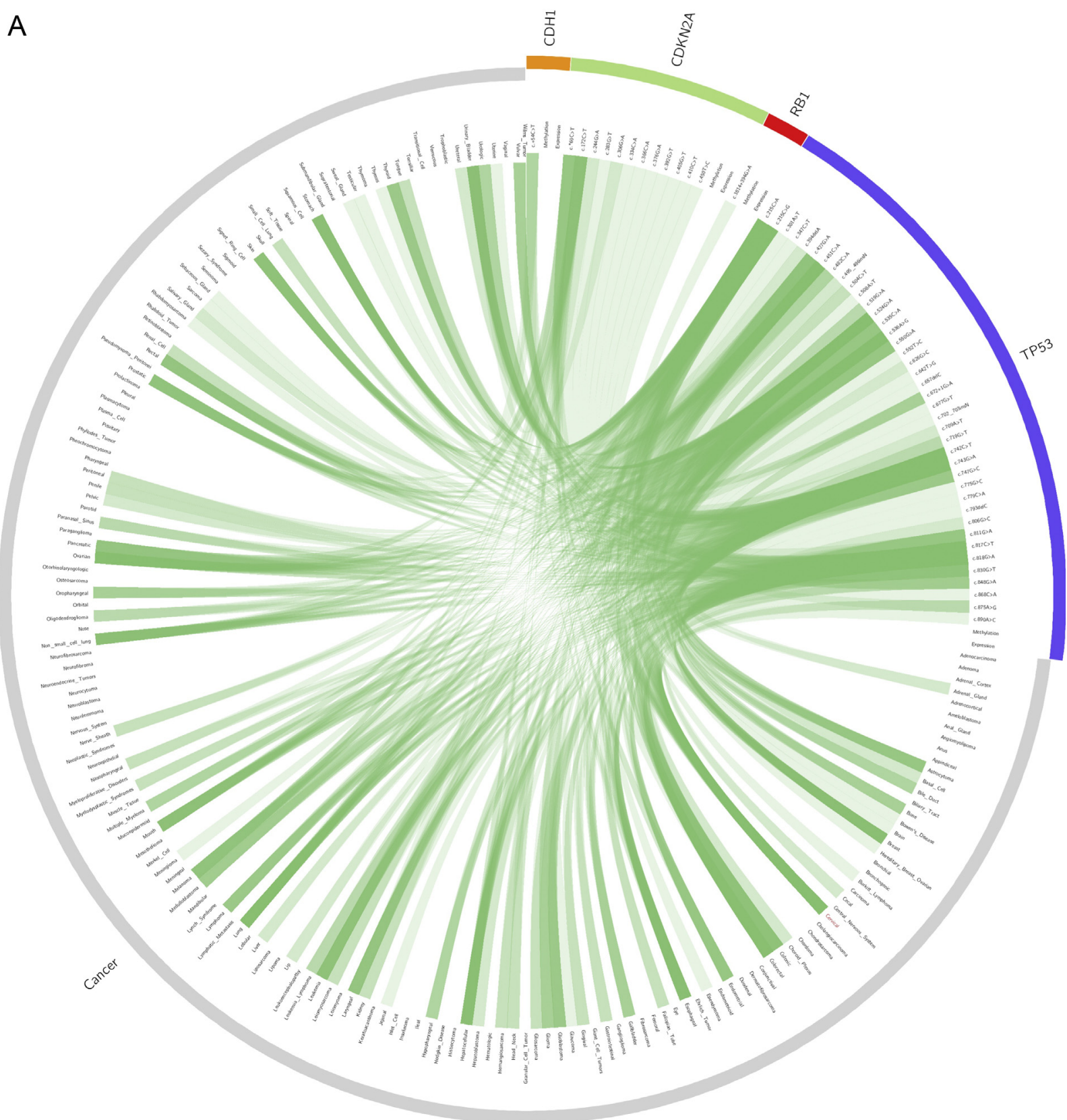

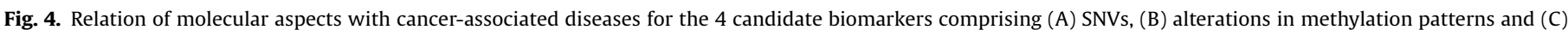
deregulation of mRNA/protein expression.

low-grade squamous intraepithelial lesions (LSIL), 98 high-grade squamous intraepithelial lesions (HSIL), 16 SCC and 2 AC. The levels of $\mathrm{p} 16^{\mathrm{INK} 4}$ increased with the severity of the cervical lesions $(\mathrm{p}<0.05)$ [23], and similar results were obtained in 20 HSIL, 42 LSIL, 50 atypical squamous cells of undetermined significance (ASCUS), 20 cervical cancer and 17 normal samples ( $<<0.05$ ) [25]. Furthermore, another study with 30 normal cervix samples, 150 CIN lesions and 50 cervical cancer samples showed the overexpression of $\mathrm{p} 16^{\mathrm{INK} 4}$, which was associated with poor cervical cancer prognosis $(\mathrm{p}<0.05)$ [26]. The levels of $\mathrm{p} 16^{\text {INK4 }}$ and $\mathrm{p} 14^{\text {ARF }}$ were evaluated in 5 cervical cell lines, 48 normal samples and 48 HSIL samples, and showed a 6.27 and 4.87-fold increase, respectively, compared to the normal samples [27]. It is interesting to note that although higher $\mathrm{p} 16^{\text {INK4 }}$ levels were significantly associated with the progression of cervical lesions to cervical cancer $(p=0.001)$, no CDKN2A variant was linked to the increase in protein levels [24], indicating that different types of regulation other than methylation events could be involved and should be evaluated.

Deregulation of the RB1 gene has been reported in 67 types of cancer. Similar to p53, pRB is also affected by high-risk HPV infection. In this case, upon binding of oncoprotein E7, the complex of pRB with E2F is disrupted, leading to the expression of E2F responsive genes and pRB degradation [48,49]. A study in 130 cervix samples showed decreasing levels of pRB with increasing severity of the cervical lesions $(p=0.01)$ [24], and similar results were observed in a study with 114 cervical tissue samples [50]. However, a study in 98 samples of cervical neoplastic lesions showed no alteration in the expression of pRB compared to the normal samples [51]. It has also been demonstrated that the inhibition of HPV16 E7 can restore the activity of pRB [52]. 


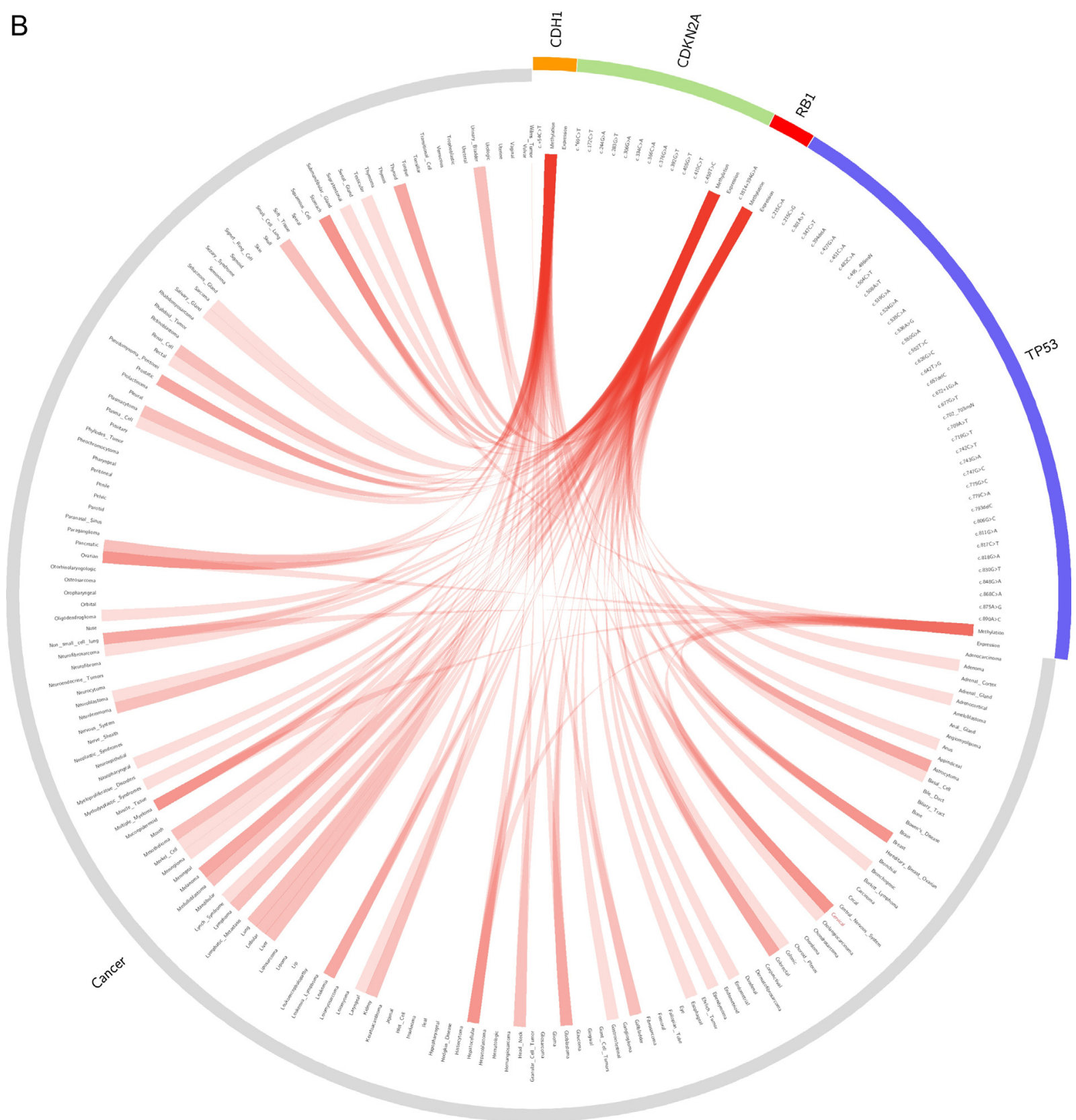

Fig. 4. (Continued)

Evaluation of CDH1 expression was performed in 60 types of cancer. For cervical cancer, a study in 40 patients with HSIL caused by HPV16 infection showed lower levels of E-cadherin upon the expression of HPV16 E6/E7 genes $(p<0.01)$ [18]. This decrease led to the promotion of cell proliferation and increase in cell migration and invasion due to weaker cell adhesion properties [53]. Additionally, reduced levels of E-cadherin and $\beta$-catenin were observed in 135 cervical cancer samples, which was associated with histological differentiation $(\mathrm{p}<0.001)$, metastasis $(\mathrm{p}<0.001)$ and recurrence $(\mathrm{p}<0.001)$ [19], suggesting that the E-cadherin status could be used as prognostic biomarker.

\section{Gene interactions networks}

To determine the metabolic importance of CDH1, CDKN2A, RB1 and TP53 genes in the development of cervical cancer, their metabolic pathways were studied, by text and data mining of scientific papers, together with the molecules related to HPV infection. Additionally, the molecular interactions with the other 10 genes were also investigated for cervical cancer in order to assess their role in cervical carcinogenesis (Fig. 5).

\subsection{Tumour suppressor pathways}

The epidermal growth factor receptor (EGFR) pathway regulates cell growth, cellular maturation, proliferation, inhibition of apoptosis, angiogenesis and metastasis [54]. EGFR is known to be activated by binding to different ligands and stimulating the dimerization of the receptor. The dimerization induces the activation of the tyrosine kinase domain, which leads to autophosphorylation and recruitment of a range of adaptor proteins such as growth factor receptor bound protein2 (GRB2) and the proto-oncogene tyrosine protein kinase $(\mathrm{Src})$. The intracellular signalling cascades affect gene transcription, which in turn 


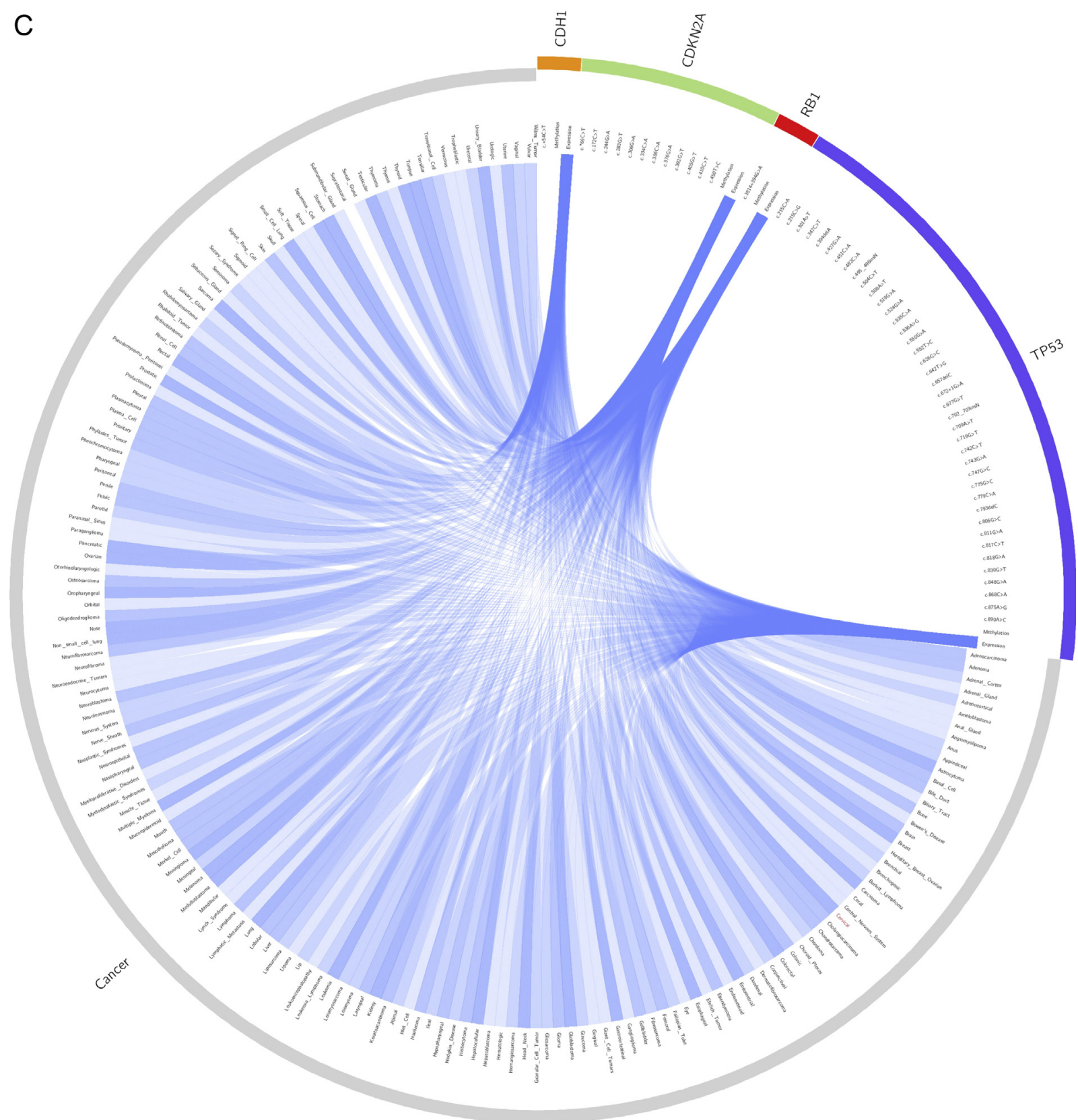

Fig. 4. (Continued)

promotes cancer cell proliferation, reduces apoptosis, increases invasion and metastasis and stimulates tumour-induced angiogenesis [55].

E-cadherin and H-cadherin (CDH13) play key roles in cellcell adhesion, being involved in EGFR inhibition through the negative regulation of ligand binding [56,57]. Low expression of CDH1 gene can facilitate EGFR signalling, and disruptions in the function of E-cadherin leads to the enhancement of this pathway and changes in cell-cell and cell-matrix adhesion. This can increase the severity of the cervical lesions and induce metastasis [58]. The downregulation of $\mathrm{CDH} 13$ as a result of hypermethylation, is also associated with poor disease-free survival [17], possibly due to the lack of inhibition of the EGFR pathway. However, further analysis should be performed to elucidate the contributions of epigenetic events and gene variants on the function of the protein if the $\mathrm{CDH} 13$ methylation status is cannot be well-established $[14,17,59]$.
Additionally, it is not clear how the variant allele in CDH1 c. *54C $>$ T confers protection against cervical cancer [12].

In the EGFR pathway, Src kinase phosphorylates fragile histidine triad (FHIT), a tumour suppressor protein, to inactivate it and target it for proteasomal degradation in cancer cells. The tumour supressor properties of FHIT include the ability to induce apoptosis, arrest cell cycle and suppress tumourigenesis in nude mice [60]. High-risk HPV infections can induce FHIT loss of heterozygosity $(\mathrm{LOH})$ in cervical cancer patients [61]. The epigenetic deregulation of FHIT $[14,45,59,62,63]$ appears to be a late event during cervical carcinogenesis [64], arising from high instability in response to genotoxicities or replicative stress [65]. Smoking habits in patients with cervical cancer contribute to the homo/hemizygous deletion and downregulation of FHIT [66]. However, some variants can lead to the loss of protein function as reported in the case of the c.293A > G missense SNV at codon 35 (histidine is replaced by an arginine) or the absence of exon 5 [67]. 


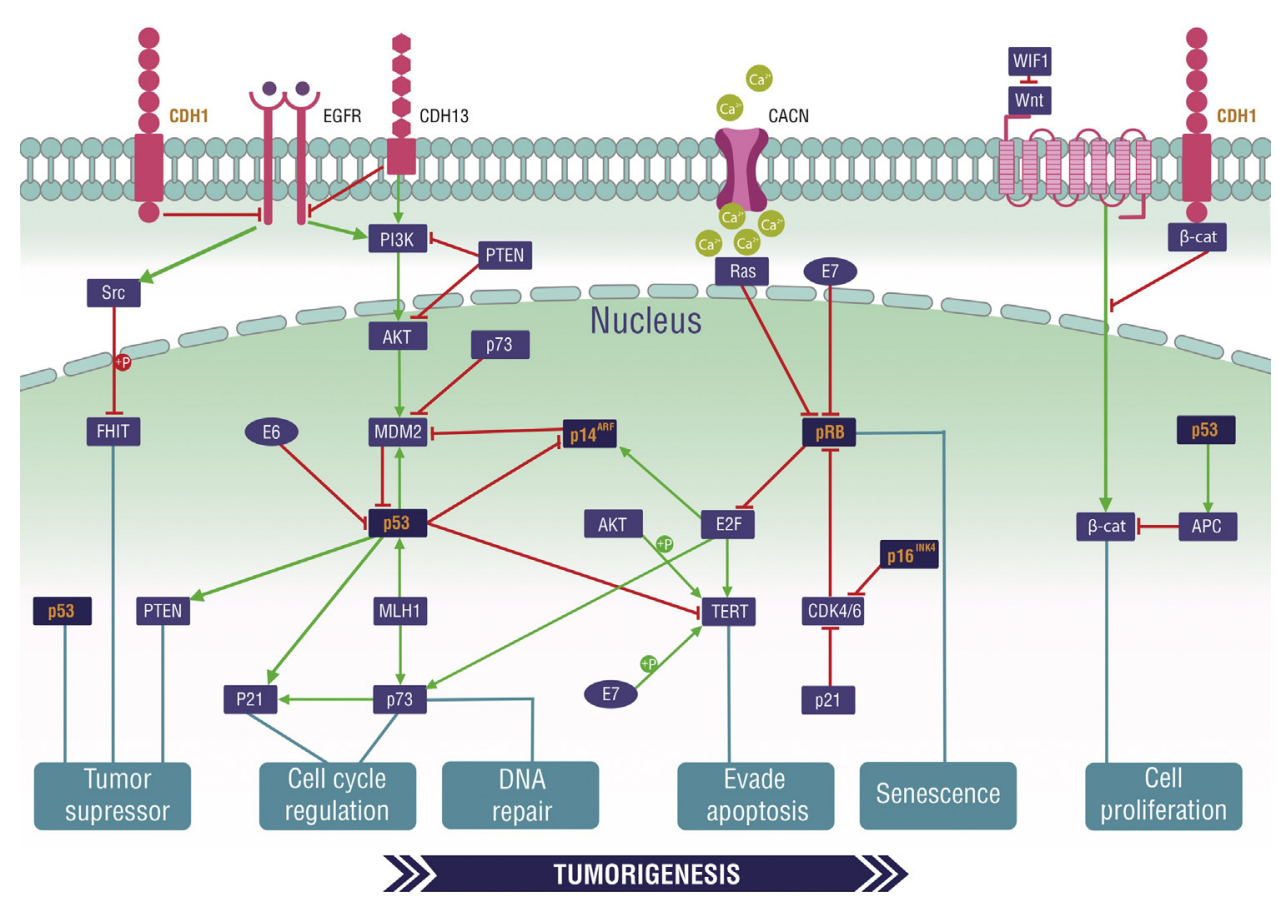

Fig. 5. Metabolic interaction networks including the four putative biomarkers and 10 possible biomarkers and their cellular outcomes.

Together with low levels of FHIT, elevated levels of p53 are related a higher recurrence of cervical cancer [68] resulting in worse prognosis. The tumour suppressor properties of TP53 result from its antiproliferative functions as it can induce G1 arrest (by functioning as a cell-cycle checkpoint), senescence (by causing permanent cell cycle arrest) and modulate autophagy [69]. Allelic imbalance in TP53 was shown to be associated with a reduced relapse-free survival [70], reinforcing its importance in the maintenance of cancer and indicating it as a putative predictor of poor prognosis.

\subsection{Cell cycle regulation and DNA repair}

Cell cycle dysregulation is one of the main mechanisms by which cancers develops. The ability to sustain proliferation in response to continuous growth-stimulatory signals is a hallmark of cancer development, translating into the evasion from growth suppressors [71]. The phosphatidylinositol 3-kinase (PI3K) pathway is one of the most relevant pathways in cancer due to its role in apoptosis prevention, cellular survival and proliferation promotion. Activation of the PI3K pathway is able to stimulate transmembrane tyrosine kinase receptors, such as EGFR, promoting its dimerization and leading to the phosphorylation of PtdIns $(4,5) \mathrm{P}_{2}$ (PIP2) into PtdIns(3,4,5) $\mathrm{P}_{3}$ (PIP3), which acts as second messenger in the cell [72]. PIP3 is the principal mediator of the PI3K pathway, and protein kinase B (AKT) is one of the most important downstream effectors, which can activate other important pathways, such as the rapamycin complex 1 (mTORC1) [73]. The PI3K signalling pathway can be inhibited by phosphatase and tensin-homologue (PTEN) through the conversion of PIP3 into PIP2. Similar to p53, PTEN has several tumour suppressor properties and can affect cellular functions such as survival, proliferation, energy metabolism and cellular architecture [74].

Regulation of PTEN expression can occur at several levels. In cervical cancer, PTEN variants were shown to be associated with HPV-negative adenocarcinoma [75], although it was not reproduced in other studies [76]. The epigenetic regulation of gene expression seems to be relevant for PTEN as it is hypermethylated in cervical cancer and associated with the disease stage [77] and histological type [78], which is consistent with lower levels of PTEN and PTEN silencing [76,79]. The methylation events were also reported to be affected by the SNV in the CpG islands c.-9C $>$ G, which modifies the methylation status and thus gene expression [80]. PTEN c.273delA, located in the functional domain of PTEN can interfere with the function of PTEN [81], showing the importance of the loss of function of PTEN in cancer development.

The p53 protein, a well-known tumour suppressor, is located downstream of the PI3K pathway and is tightly regulated by the proto-oncogene MDM2 (MDM2), p14 ${ }^{\mathrm{ARF}}$, p73 and MutL homolog 1 (MLH1). It stimulates the expression of p21 to arrest cell cycle and its inactivation through the oncoprotein effects of HPV-E6 on the cell cycle leads to a cascade of deregulating events that induces cell proliferation. $\mathrm{p} 53$ is regulated by cyclin dependent kinase inhibitor 1A (CDKN1A), which is also activated by p73 (TAp73). p21 acts as regulator of cell cycle and inhibits the activity of $\mathrm{CDK} 2$, which is required for the phosphorylation of pRB [82]. Thus, it is important to determine the impact of variants in this gene. In Chinese and in non-Asian women, the missense variant c.93C $>$ A located in codon 31 was associated with protective effects against cervical cancer $[83,84]$. In the Brazilian population, c.93C $>A$ and c. ${ }^{*} 20 \mathrm{C}>\mathrm{T}$ (located in $3^{\prime} \mathrm{UTR}$ ) variants of CDKN1A were also associated with protection against cervical cancer [85]. CDKN1A was found to be hypermethylated in less than $10 \%$ of cervical cancer samples [31]. This is consistent with the reports of high levels of p21 in cervical cancer samples, which was also shown to be associated with the progression of lesions in several studies [23,24,86,87].

The gene encoding tumour suppressor 73 (TP73) is a functional and structural homologue of $\mathrm{p} 53$ that codes for multiple proteins through alternative splicing. There are mainly two isoforms of this gene: TAp73, which is a full length protein containing a transactivation domain (TA) that is able to activate other genes and induce apoptosis and $\Delta \mathrm{Np} 73$, the $\mathrm{NH} 2$-terminal truncated isoform that acts as an inhibitor of TAp73 [88]. Epigenetic deregulation of TP73 is dependent on the production of highrisk HPV E6 and E7 oncoproteins leading to cellular immortalization [89]. This gene is also hypermethylated to a higher degree in AC than in SCC. Hypermethylation in the promoter region of TP73 not only increases the risk of cervical cancer by 1.81 -fold [31] but is 
also associated with lower expression levels of the protein. Furthermore, the TAp73 gene was found to be overexpressed in radiosensitive cervical cancer cells, and $\Delta \mathrm{Np} 73$ overexpression was correlated with resistance to radiation and worse outcome [88], thus indicating the epigenetic and expression deregulation of TP73 as potential prognostic biomarkers in cervical carcinogenesis. Although there is a lack of association of SNVs in NearGene-5 of TP73 (c.-20G > A and c.-30C > T) with cervical cancer [90], its presence may have consequences in the methylation status and expression of TP73.

The regulation of these proteins is very tight. Increased p73 levels were found to be associated with higher levels of the p21 protein [91]. Both p53 and p73 proteins can be stimulated by the MLH1 protein, thereby affecting the cell cycle regulation. MLH1 also participates in intracellular processes for recognizing and repairing foreign DNA, by a process called DNA mismatch repair. Sequence variants in a set of proteins involved in this process, including MLH1, have been shown to increase the susceptibility to cancer due to the high levels of microsatellite instability [92]. Hypermethylation of the MLH1 promoter has been reported in cervical cancer [93] and is associated with low-risk HPV infection [94]. Significant lower levels of MLH1 has been found in invasive cervical cancer (ICC) samples [95], suggesting that the loss of MLH1 protein is associated with neoplastic invasiveness [96]. Reduced levels of MLH1, FHIT together with increased levels of $\mathrm{p} 53$ proteins have been considered indicators of higher recurrence of cervical cancer [68], which could be an indicative of their potential as candidates for cervical cancer prognosis.

\subsection{Senescence and apoptosis evasion pathways}

Calcium voltage-gated channel auxiliary subunit alpha2 delta2 (CACNA2D2) is a member of the calcium channel family, CACN. The input of $\mathrm{Ca}^{2+}$ into the cytoplasm is one of the mechanisms by which the RAS pathway is activated [97]. There are very few studies investigating the role of CACNA2D2 in cervical cancer but its presence in a locus deleted in $15 \%$ of cervical cancer samples suggests that it could be a tumour suppressor gene [98]. In fact, the CACNA2D2 loci was found to be deleted in 50\% of cervical cancer samples or its increased methylation level, which ranged from $9 \%$ to $27 \%$, was shown to promote the progression from CIN to cervical cancer, resulting in over 5 times reduction in CACNA2D2 expression in cervical cancer samples in comparison with normal samples [99].

The RAS pathway leads to cell growth, differentiation and survival once the Ras protein inhibits pRb. pRB is maintained in an active hypophosphorylated state by $\mathrm{p} 16^{\mathrm{INK} 4}$ and is able to repress the E2F-mediated transcription, inducing cell cycle arrest and senescence [100]. The downregulation of $\mathrm{pRb}$ is related to the activation of p53 by increasing levels of E2F, thereby stimulating $\mathrm{p} 14^{\mathrm{ARF}}$. p14 ${ }^{\mathrm{ARF}}$ inhibits MDM2 [101], an important negative regulator of p53 and pRB, which promotes proliferation by stimulating the $S$ phase through the induction of the transcriptional activity of E2F1/DP1. AKT and E2F are responsible for phosphorylation and activation of telomerase reverse transcriptase (TERT), an oncogene responsible for telomere elongation that allows the cells to evade apoptosis [102]. HPV16 E6 binds to the TERT promoter and induces its expression, leading to significant higher levels of TERT in the cervical cancer samples $[103,104]$ as well as the upregulation of vascular endothelial growth factor (VEGF) [105], which contributes for tumour angiogenesis. Silencing of TERT leads to the suppression of cell proliferation, cell cycle, cell migration and invasion leading to the induction of apoptosis, thereby suppressing the growth of cervical cancer cells in vitro [106].
However, hypermethylation of the TERT promoter was found to be significant in CIN3 lesions [107] and cervical cancer samples [108]. TERT promoter variants c. $-146 \mathrm{C}>\mathrm{T}$ and c.-124C $>$ T were observed in $21.4 \%$ of cervical cancer patients in India, which is almost 4 times higher than the proportions reported by studies in Western populations [109].

\subsection{Cell proliferation}

The Wnt signalling pathway is a major regulator of cell proliferation, migration, differentiation and tumour progression [110] and is important for cervical cancer formation as it is affected by several genes included in this study, such as CDH1, Wnt inhibitory factor 1 (WIF1) and adenomatous polyposis coli (APC). The Wnt pathway plays a key role in cell proliferation via the transcriptional activation by $\beta$-catenin mediated through the binding of E-cadherin. On the other hand, WIF1 inhibits ligation of Wnt to its receptor frizzled, leading to the activation of the Axin complex and constant degradation of $\beta$-catenin [110], which prevents signalling by the Wnt pathway. This has been implicated in the inhibition of tumour proliferation, invasion, angiogenesis and apoptosis [111]. Hypermethylation of WIF1 was detected in approximately $87 \%$ of the cervical cancer samples [14,112], which could be correlated to low levels or absence of WIF1 protein in the cervical cancer samples [111].

APC, another negative regulator of Wnt pathway, is involved not only in the Axin complex but also in actin assembly, cell-to-cell adhesion and microtubule network formation [113]. APC hypermethylation was found in cancer cell lines but was absent in HPVimmortalized cell lines [114], indicating that genetic silencing due to methylation may be a later event in transformation or might be cell cycle dependent [114]. In cervical cancer samples, APC hypermethylation was significantly higher in AC compared to SCC $[16,115]$. Low levels of APC in the cytoplasm was correlated with high levels of $\beta$-catenin in the nucleus and cytoplasm of cervical cancer cells, suggesting the activation of the Wnt pathway [116]. In HeLa and CaSki cells, treatment with hydralazine promotes APC demethylation, inducing the expression of APC and leading to growth inhibition [117]. This shows the importance of the Wnt signalling pathway in the development of cervical cancer and denotes WIF1 and APC as therapeutic targets in cervical cancer.

\section{Conclusion}

The process of finding compelling biomarkers for the development or prognosis of cervical cancer is complex. In this study, it was possible to unveil four putative biomarkers that are significantly correlated with the development and maintenance of cervical cancer due to the presence of variants in the respective genes, alterations in gene methylation patterns and deregulated expression patterns. Further studies should be performed to elucidate the role of these four genes as well as to include the others ten possible genes that lack studies with significance due to the inconsistency of the number of patients and chosen methodology to determine the presence of SNV, methylation status and expression deregulation in these genes. This will allow the development of a robust genetic panel for the early diagnosis and evaluation of prognosis of cervical cancer as has been already observed for other types of cancers.

\section{Conflict of interest statement}

The authors declare that there are no conflict of interest. 


\section{Acknowledgments}

This work was funded by the Foundation for Science and Technology of the state of Pernambuco (FACEPE). The authors are grateful to Vinicius Albertin Tigre da Costa for his contributions to the construction of the figures.

\section{Appendix A. Supplementary data}

\section{Supplementary data associated with this article can be found, in the online version, at http://dx.doi.org/10.1016/j.} mrrev.2017.06.002.

\section{References}

[1] J. Ferlay, I. Soerjomataram, M. Ervik, R. Dikshit, S. Eser, C. Mathers, M. Rebelo, D. Parkin, D. Forman, F. Bray, GLOBOCAN 2012 v1.0, cancer incidence and mortality worldwide: IARC CancerBase No. 11, lyon, Fr. Int. Agency Res. Cancer (2012) 2012. http://globocan.iarc.fr (Accessed 28 October 2016).

[2] S.V. Bava, A.K.T. Thulasidasan, C.N. Sreekanth, Cervical cancer: a comprehensive approach towards extermination, Ann. Med. 48 (2016) 149-161, doi:http://dx.doi.org/10.3109/07853890.2016.1145796.

[3] J.W. Kim, S.H. Song, C.H. Jin, J.K. Lee, N.W. Lee, K.W. Lee, Factors affecting the clearance of high-risk human papillomavirus infection and the progression of cervical intraepithelial neoplasia, J. Int. Med. Res. 40 (2012) 486-496.

[4] M. Molano, A. Van den Brule, M. Plummer, E. Weiderpass, H. Posso, A. Arslan, Meijer C.J.L.M, N. Muñoz, S. Franceschi, Determinants of clearance of human papillomavirus infections in Colombian women with normal cytology: a population-based, 5-year follow-up study, Am. J. Epidemiol. 158 (2003) $486-$ 494, doi:http://dx.doi.org/10.1093/aje/kwg171.

[5] L.A. Torre, R.L. Siegel, E.M. Ward, A. Jemal, Global cancer incidence and mortality rates and trends - an update, Cancer Epidemiol. Biomarkers Prev. 25 (2016) 16-27, doi:http://dx.doi.org/10.1158/1055-9965 (EPI-15-0578)

[6] I.I. Daud, M.E. Scott, Y. Ma, S. Shiboski, S. Farhat, A.B. Moscicki, Association between toll-like receptor expression and human papillomavirus type 16 persistence, Int. J. Cancer 128 (2011) 879-886, doi:http://dx.doi.org/10.1002/ ijc. 25400 .

[7] C.B. Buck, P.M. Day, C.D. Thompson, J. Lubkowski, W. Lu, D.R. Lowy, J.T. Schiller, Human alpha-defensins block papillomavirus infection, Proc. Natl. Acad. Sci. U. S. A. 103 (2006) 1516-1521, doi:http://dx.doi.org/10.1073/ pnas.0508033103.

[8] I.H. Frazer, Interaction of human papillomaviruses with the host immune system: a well evolved relationship, Virology 384 (2009) 410-414, doi:http:// dx.doi.org/10.1016/j.virol.2008.10.004.

[9] C. on A.I.A.S.B. and G.F. in Health, Genes, Behavior, and the social environment, The National Academies Press, 2006.

[10] C. Bellcross, W.D. Dotson, Tumor gene expression profiling in women with breast cancer, PLoS Curr. 2 (2010) RRN1178, doi:http://dx.doi.org/10.1371/ currents.RRN1178.

[11] D. Cragun, C. Radford, J.S. Dolinsky, M. Caldwell, E. Chao, T. Pal, Panel-based testing for inherited colorectal cancer: a descriptive study of clinical testing performed by a US laboratory, Clin. Genet. 86 (2014) 510-520, doi:http://dx. doi.org/10.1111/cge.12359.

[12] Y. Li, Y. Tang, R. Zhou, D. Sun, Y. Duan, N. Wang, Z. Chen, N. Shen, Genetic polymorphism in the $3^{\prime}$-untranslated region of the E-cadherin gene is associated with risk of different cancers, Mol. Carcinog. 50 (2011) 857-862, doi:http://dx.doi.org/10.1002/mc.20765.

[13] R. Abudukadeer, G. Bakry, A. Mutz-Dehbalaie, G.K. Widschwendter, H. Fiegl, Clinical relevance of $\mathrm{CDH} 1$ and $\mathrm{CDH} 13$ DNA-methylation in serum of cervical cancer patients, Int. J. Mol. Sci. 13 (2012) 8353-8363, doi:http://dx.doi.org 10.3390/ijms13078353.

[14] E.M. Siegel, B.M. Riggs, A.L. Delmas, A. Koch, A. Hakam, K.D. Brown, Quantitative DNA methylation analysis of candidate genes in cervical cancer, PLoS One 10 (2015) e0122495, doi:http://dx.doi.org/10.1371/journal. pone.0122495.

[15] S. Pathak, N. Bhatla, N. Singh, Cervical cancer pathogenesis is associated with one-carbon metabolism, Mol. Cell. Biochem. 369 (2012) 1-7, doi:http://dx. doi.org/10.1007/s11010-012-1362-3.

[16] G. Narayan, H. Arias-pulido, S. Koul, H. Vargas, F.F. Zhang, J. Villella, A Schneider, M.B. Terry, M. Mansukhani, V.V. Murty, Frequent promoter methylation of CDH1 DAPK, RARB, and HIC1 genes in carcinoma of cervix uteri: its relationship to clinical outcome, Mol. Cancer 2 (2003) 24.

[17] L. Widschwendter, A. Ivarsson, H. Müller, A. Fiegl, G. Müller-Holzner, C. Goebel, M. Marth, CDH1 and CDH13 methylation in serum is an independent prognostic marker in cervical cancer patients, Int. J. Cancer 109 (2004) 163166, doi:http://dx.doi.org/10.1002/ijc.11706.

[18] Y. Liu, W. Qian, J. Zhang, Y. Dong, C. Shi, Z. Liu, S. Wu, The indicative function of Twist2 and E-cadherin in HPV oncogene-induced epithelial-mesenchymal transition of cervical cancer cells, Oncol. Rep. 33 (2015) 639-650, doi:http:/ dx.doi.org/10.3892/or.2014.3620.
[19] Y. Cheng, Y. Zhou, W. Jiang, X. Yang, J. Zhu, D. Feng, Y. Wei, M. Li, F. Yao, W. Hu, W. Xiao, B. Ling, Significance of E-cadherin, $\beta$-catenin, and vimentin expression as postoperative prognosis indicators in cervical squamous cell carcinoma, Hum. Pathol. 43 (2012) 1213-1220, doi:http://dx.doi.org/10.1016/ j.humpath.2011.08.025.

[20] N. Thakur, S. Hussain, V. Nasare, B.C. Das, S.F. Basir, M. Bharadwaj, Association analysis of p16 (CDKN2A) and RB1 polymorphisms with susceptibility to cervical cancer in Indian population, Mol. Biol. Rep. 39 (2012) 407-414, doi: http://dx.doi.org/10.1007/s11033-011-0752-z.

[21] M.Y. D.H. Jeong, Y.N. Youm, K.B. Kim, M.S. Lee, H.K. Sung, K.T. Kim Yoon, Promoter methylation of p16, DAPK, CDH1, and TIMP-3 genes in cervical cancer: correlation with clinicopathologic characteristics, Int. J. Gynecol. Cancer (2006) 1234-1240.

[22] N.A. Wijetunga, T.J. Belbin, R.D. Burk, K. Whitney, M. Abadi, J.M. Greally, M.H. Einstein, N.F. Schlecht, Gynecologic Oncology Novel epigenetic changes in CDKN2A are associated with progression of cervical intraepithelial neoplasia, Gynecol. Oncol. 142 (2016) 566-573, doi:http://dx.doi.org/10.1016/j. ygyno.2016.07.006.

[23] E.A. Portari, B. Russomano, M.J. Camargo, C.R.M. Gayer, M.J. Guillobel, C.B. Santos-rebouças, J.M.B. Macedo, Immunohistochemical expression of cyclin D1, p16Ink4a, p21WAF1, and Ki-67 correlates with the severity of cervical neoplasia, Int. J. Gynecol. Pathol. 32 (2013) 501-508, doi:http://dx.doi.org/ 10.1097/PGP.0b013e31826f5cf6.

[24] A.A. Bahnassy, A.R.N. Zekri, M. Saleh, M. Lotayef, M. Moneir, O. Shawki, The possible role of cell cycle regulators in multistep process of HPV-associated cervical carcinoma, BMC Clin. Pathol. 7 (2007) 4, doi:http://dx.doi.org/ 10.1186/1472-6890-7-4.

[25] C. Zhang, W.E.I. Bao, L. Wang, Downregulation of p16INK4A inhibits cell proliferation and induces G1 cell cycle arrest in cervical cancer cells, Int. J. Mol. Med. 33 (2014) 1577-1585, doi:http://dx.doi.org/10.3892/ ijmm.2014.1731.

[26] H. Liu, Y. Wang, L. Wang, M. Hao, P16INK4A and survivin. Diagnostic and prognostic markers in cervical intraepithelial neoplasia and cervical squamous cell carcinoma, Exp. Mol. Pathol. 99 (2015) 44-49, doi:http://dx. doi.org/10.1016/j.yexmp.2015.04.004.

[27] H. Von Keyserling, W. Ku, A. Schneider, T. Bergmann, A.M. Kaufmann, p16 INK4a and p14 ARF mRNA expression in Pap smears is age-related, Mod. Pathol. 25 (2012) 465-470, doi:http://dx.doi.org/10.1038/ modpathol.2011.179.

[28] T.M. McCormick, N.H.S. Canedo, Y.L. Furtado, F.A. Silveira, R.J. de Lima, A.D.F. Rosman, G.L. Almeida Filho, M. da G. da C. Carvalho, Association between human papillomavirus and Epstein - Barr virus DNA and gene promoter methylation of RB1 and CDH1 in the cervical lesions: a transversal study, Diagn. Pathol. 10 (2015) 59, doi:http://dx.doi.org/10.1186/s13000-015-02833.

[29] R. F. Yuan, P. Sun, Y. Chen, S. Ni Liang, Combined analysis of pri-miR-34b/c rs4938723 and TP 53 Arg72Pro with cervical cancer risk, Tumor Biol. (2016) 6267-6273, doi:http://dx.doi.org/10.1007/s13277-015-4467-y.

[30] S. Yang, Y. Cai, P. Jiang, W. Li, J. Tang, Association of a miR-502-Binding site single nucleotide polymorphism in the 3' - Untranslated region of SET8 and the TP53 codon 72 polymorphism with cervical cancer in the chinese population, Asian Pac. J. Cancer Prev. 15 (2014) 6505-6510.

[31] M. Jha, V. Nikbakht, A. Jain, N. Sehgal, Promoter hypermethylation of p73 and p53 genes in cervical cancer patients among north Indian population, Mol. Biol. Rep. 39 (2012) 9145-9157, doi:http://dx.doi.org/10.1007/s11033-0121787-5.

[32] S. Cai, K. Han, Research on expression and importance of p53, p16 and VEGF-C in cervical cancer, J. Gynecol. Obstet. Biol. La Reprod. 44 (2015) 639-645, doi: http://dx.doi.org/10.1016/j.jgyn.2014.07.012.

[33] L. Liu, X. Li, H. Chen, J. Cui, D. Xu, Significance of Ebp1 and p53 protein expression in cervical cancer, Genet. Mol. Res. 14 (2015) 11860-11866, doi: http://dx.doi.org/10.4238/2015.October.2.19.

[34] F. van Roy, G. Berx, The cell-cell adhesion molecule E-cadherin, Cell. Mol. Life Sci. 65 (2008) 3756-3788, doi:http://dx.doi.org/10.1007/s00018-008-82811.

[35] Y.M. X.F. Zhang, H. Wang, Y.Y. Ge, Z.F. Cao, D.G. Chen, W. Wen, N. Guo, Y. Wang, J.H. Zhang Li, Association of CDH1 single nucleotide polymorphisms with susceptibility to esophageal squamous cell carcinomas and gastric cardia carcinomas, Dis. Esophagus 21 (2008) 21-29, doi:http://dx.doi.org/10.1111/ j.1442-2050..00724.x

[36] C. Giacinti, A. Giordano, RB and cell cycle progression, Oncogene 25 (2006) 5220-5227, doi:http://dx.doi.org/10.1038/sj.onc.1209615.

[37] L. Mao, A. Merlo, G. Bedi, G.I. Shapiro, C.D. Edwards, B.J. Rollins, D. Sidransky, A novel pl6INK4A transcript, Cancer Res. 55 (1995) 2995-2997.

[38] H. Kanao, T. Enomoto, Y. Ueda, M. Fujita, R. Nakashima, Y. Ueno, T. Miyatake, T. Yoshizaki, G.S. Buzard, T. Kimura, K. Yoshino, Y. Murata, Correlation between p14(ARF)/p16(INK4A) expression and HPV infection in uterine cervical cancer, Cancer Lett. 213 (2004) 31-37, doi:http://dx.doi.org/10.1016/j. canlet.2004.03.030.

[39] A. Chansaenroj, P. Theamboonlers, S. Junyangdikul, A. Swangvaree, T. Karalak, Polymorphisms in TP53 (rs1042522), p16 (rs11515 and rs3088440) and NQ01 (rs1800566) genes in Thai cervical cancer patients with HPV 16 infection, Asian Pac. J. Cancer Prev. 14 (2013) 341-346. http://www.ncbi.nlm.nih.gov/ pubmed/23534750.

[40] M.L. Tornesello, L. Buonaguro, F.M. Buonaguro, Mutations of the TP53 gene in adenocarcinoma and squamous cell carcinoma of the cervix: a systematic 
review, Gynecol. Oncol. 128 (2013) 442-448, doi:http://dx.doi.org/10.1016/j. ygyno.2012.11.017.

[41] I.P. Pogribny, S.J. James, Reduction of p53 gene expression in human primary hepatocellular carcinoma is associated with promoter region methylation without coding region mutation, Cancer Lett. 176 (2002) 169-174, doi:http:// dx.doi.org/10.1016/S0304-3835(01)00748-0.

[42] J.H. Kang, S.J. Kim, D.-Y. Noh, I.A. Park, K.J. Choe, O.J. Yoo, H.-S. Kang, Methylation in the p53 promoter is a supplementary route to breast carcinogenesis: correlation between $\mathrm{CpG}$ methylation in the p53 promoter and the mutation of the p53 gene in the progression from ductal carcinoma in situ to invasive ductal carcinoma, Lab. Investig. 81 (2001) 573-579, doi: http://dx.doi.org/10.1038/labinvest.3780266.

[43] M. Chmelarova, E. Krepinska, J. Spacek, J. Laco, M. Beranek, V. Palicka, Methylation in the p53 promoter in epithelial ovarian cancer, Clin. Transl. Oncol.15 (2012) 160-163, doi:http://dx.doi.org/10.1007/s12094-012-0894-z.

[44] G.J. Nuovo, T.W. Plaia, S.A. Belinsky, S.B. Baylin, J.G. Herman, In situ detection of the hypermethylation-induced inactivation of the p16 gene as an early event in oncogenesis, PNAS 96 (1999) 12754-12759.

[45] C. Banzai, K. Nishino, J. Quan, K. Yoshihara, M. Sekine, T. Yahata, K. Tanaka, Promoter methylation of DAPK1, FHIT, MGMT, and CDKN2A genes in cervical carcinoma, Int. J. Clin. Oncol. 19 (2014) 127-132, doi:http://dx.doi.org/ 10.1007/s10147-013-0530-0.

[46] M.A. Khan, A. Hussain, M.K. Sundaram, U. Alalami, (-) -Epigallocatechin-3gallate reverses the expression of various tumor-suppressor genes by inhibiting DNA methyltransferases and histone deacetylases in human cervical cancer cells, Oncol. Rep. 33 (2015) 1976-1984, doi:http://dx.doi.org/ 10.3892/or.2015.3802.

[47] B. Tummers, S.H. Van Der Burg, High-risk human papillomavirus targets crossroads in immune signaling, Viruses 7 (2015) 2485-2506, doi:http://dx. doi.org/10.3390/v7052485.

[48] S. Shukla, S. Mahata, G. Shishodia, A. Pandey, A. Tyagi, Functional regulatory role of STAT3 in HPV16-Mediated cervical carcinogenesis, PLoS One 8 (2013) e67849, doi:http://dx.doi.org/10.1371/journal.pone.0067849.

[49] C.A. Moody, L.A. Laimins, Human papillomavirus oncoproteins: pathways to transformation, Nat. Rev. Cancer 10 (2010) 550-560, doi:http://dx.doi.org/ $10.1038 / \operatorname{nrc} 2886$

[50] B. Tringler, C.J. Gup, M. Singh, S. Groshong, A.L. Shroyer, D.E. Heinz, K.R. Shroyer, Evaluation of p16INK4a and pRb expression in cervical squamous and glandular neoplasia, Hum. Pathol. 35 (2004) 689-696, doi:http://dx.doi. org/10.1016/j.humpath.2004.02.012.

[51] T. Sano, K. Oyama, T. Kashiwabara, Immunohistochemical overexpression of p16 protein associated with intact retinoblastoma protein expression in cervical cancer and cervical intraepithelial neoplasia, Pathol. Int. (1998) 580585.

[52] C. Guo, K. Liu, H. Luo, H. Chen, Y. Zheng, S. Sun, Q. Zhang, L. Huang, Potent antitumor effect generated by a novel human papillomavirus (HPV) antagonist peptide reactivating the pRb/E2F pathway, PLoS One 6 (2011) e17734, doi: http://dx.doi.org/10.1371/journal.pone.0017734.

[53] D. Hu, J. Zhou, F. Wang, H. Shi, Y. Li, HPV-16 E6/E7 promotes cell migration and invasion in cervical cancer via regulating cadherin switch in vitro and in vivo, Arch. Gynecol. Obstet. 292 (2015) 1345-1354, doi:http://dx.doi.org/10.1007/ s00404-015-3787-x.

[54] C. Yewale, D. Baradia, I. Vhora, S. Patil, A. Misra, Epidermal growth factor receptor targeting in cancer: a review of trends and strategies, Biomaterials 34 (2013) 8690-8707, doi:http://dx.doi.org/10.1016/j. biomaterials.2013.07.100.

[55] N. Normanno, A. De Luca, C. Bianco, L. Strizzi, M. Mancino, M.R. Maiello, A. Carotenuto, G. De Feo, F. Caponigro, D.S. Salomon, Epidermal growth factor receptor (EGFR) signaling in cancer, Gene 366 (2006) 2-16, doi:http://dx.doi. org/10.1016/j.gene.2005.10.018.

[56] G.-Y. Bae, S.-J. Choi, J.-S. Lee, J. Jo, J. Lee, J. Kim, H.-J. Cha, Loss of E-cadherin activates EGFR-MEK/ERK signaling, which promotes invasion via the ZEB1/ MMP2 axis in non-small cell lung cancer, Oncotarget 4 (2013) 2512-2522.

[57] E. Kyriakakis, K. Maslova, M. Philippova, D. Pfaff, M.B. Joshi, S.A. Buechner, P. Erne, T.J. Resink, T-Cadherin is an auxiliary negative regulator of EGFR pathway activity in cutaneous squamous cell carcinoma: impact on cell motility, J. Invest. Dermatol. 132 (2012) 2275-2285, doi:http://dx.doi.org/ 10.1038/jid.2012.131.

[58] G. Christofori, Changing neighbours, changing behaviour: cell adhesion molecule-mediated signalling during tumour progression, EMBO J. 22 (2003) $2318-2323$.

[59] Q. Feng, A. Balasubramanian, S.E. Hawes, P. Toure, S. Sow, A. Dem, B. Dembele, C.W. Critchlow, L. Xi, H. Lu, M.W. Mcintosh, A.M. Young, N.B. Kiviat, Detection of hypermethylated genes in women with and without cervical neoplasia, J. Natl. Cancer Inst. 97 (2005) 273-282, doi:http://dx.doi.org/10.1093/jnci/ dji041.

[60] F. Bianchi, A. Magnifico, C. Olgiati, N. Zanesi, Y. Pekarsky, E. Tagliabue, C.M. Croce, S. Mé Nard, M. Campiglio, P.K. Vogt, FHIT-proteasome degradation caused by mitogenic stimulation of the EGF receptor family in cancer cells, PNAS 103 (2006) 18981-18986.

[61] D. Butler, C. Collins, M. Mabruk, C.B. Walsh, M.B. Leader, E.W. Kay, Deletion of the FHIT gene in neoplastic and invasive cervical lesions is related to high-risk HPV infection but is independent of histopathological features, J. Pathol. 192 (2000) 502-510.

[62] D. Butler, C. Collins, M. Mabruk, M.B. Leader, E.W. Kay, Loss of Fhit expression as a potential marker of malignant progression in preinvasive squamous cervical cancer, Gynecol. Oncol. 86 (2002) 144-149, doi:http://dx.doi.org/ 10.1006/gyno.2002.6712.

[63] K. Ki, S. Lee, S. Tong, J. Lee, D. Song, S. Chi, Role of $5 \hat{\mathrm{a}} €^{\mathrm{TM}}-\mathrm{CpG}$ island hypermethylation of the FHIT gene in cervical carcinoma, J. Gynecol. Oncol. 19 (2008) 117-122, doi:http://dx.doi.org/10.3802/jgo.2008.19.2.117.

[64] A.K. Virmani, C. Muller, A. Rathi, S. Zoechbauer-mueller, M. Mathis, A.F Gazdar, Aberrant methylation during cervical carcinogenesis, Clin. Cancer Res. 7 (2001) 584-589.

[65] C.E. Waters, J.C. Saldivar, S.A. Hosseini, K. Huebner, The FHIT gene product: tumor suppressor and genome caretaker, Celllular Mol, Life Sci. 71 (2015) 4577-4587, doi:http://dx.doi.org/10.1007/s00018-014-1722-0.

[66] C.H. Holschneider, R.L. Baldwin, K. Tumber, C. Aoyama, B.Y. Karlan, Human cancer biology the fragile histidine triad gene: a molecular link between cigarette smoking and cervical cancer, Hum. Cancer Biol. 11 (2005) 57565763, doi:http://dx.doi.org/10.1158/1078-0432 (CCR-05-0234).

[67] M.K. Neyaz, S. Hussain, M.I. Hassan, B.C. Das, S.A. Husain, M. Bharadwaj, Novel missense mutation in FHIT gene: interpreting the effect in HPV-mediated cervical cancer in Indian women, Mol. Cell. Biochem. 335 (2010) 53-58, doi: http://dx.doi.org/10.1007/s11010-009-0240-0.

[68] A.A. Bahnassy, A.R.N. Zekri, D. Ph, M.S. Madbouly, The correlation between FHIT, P53 and MMR genes in human papillomavirus-associated cervical carcinoma, J. Egiptian Nat. Cancer. Inst. 18 (2006) 191-202.

[69] J.T. Zilfou, S.W. Lowe, Tumor suppressive functions of p53, cold spring harb, Perspect. Biol. 0 (2009) 1001883, doi:http://dx.doi.org/10.1101/cshperspect. a001883.

[70] Å.H. Elland, S.M.K. Raggerud, G.B.K. Ristensen, R.H. Olm, V.M.A. Beler, K.H. Uebner, A.B.Ø. Ale, R.A.L. Othe, Primary cervical carcinomas show 2 common regions of deletions at 3P, 1 within the FHIT gene: evaluation of allelic inbalance at FHIT, RB1 and TP53 in relation to survival, Int. J. Cancer. 88 (2000) 217-222.

[71] D. Hanahan, R.A. Weinberg, Hallmarks of cancer: the next generation, Cell 144 (2011) 646-674, doi:http://dx.doi.org/10.1016/j.cell.2011.02.013.

[72] J. Polivka, F. Janku, Molecular targets for cancer therapy in the PI3 K/AKT/ mTOR pathway, Pharmacol. Ther. 142 (2014) 164-175, doi:http://dx.doi.org/ 10.1016/j.pharmthera.2013.12.004.

[73] M. MArtini, Ma.C. de Santis, L. Braccini, F. Gulluni, E. Hirsch, PI3K/AKT signaling pathway and cancer: an updated review, Ann. Med. 46 (2014) 372383.

[74] M.S. Song, L. Salmena, P.P. Pandolfi, The functions and regulation of the PTEN tumour suppressor, Nat. Rev. Mol. Cell Biol. 13 (2012) 283-296, doi:http://dx. doi.org/10.1038/nrm3330.

[75] T. Minaguchi, H. Yoshikawa, S. Nakagawa, T. Yasugi, T. Yano, H. Iwase, K. Mizutani, K. Shiromizu, K. Ohmi, Y. Watanabe, K. Noda, M. Nishiu, Y. Nakamura, Y. Taketani, Association of PTEN mutation with HPV-negative adenocarcinoma of the uterine cervix, Cancer Lett. 210 (2004) 57-62, doi: http://dx.doi.org/10.1016/j.canlet.2004.03.017.

[76] T.-H. Cheung, K.W.-K. Lo, S.-F. Yim, L.K.-Y. Chan, M.-S. Heung, C.-S. Chan, A.Y.K. Cheung, T.K.-H. Chung, Y.-F. Wong, Epigenetic and genetic alternation of PTEN in cervical neoplasm, Gynecol. Oncol. 93 (2004) 621-627, doi:http://dx. doi.org/10.1016/j.ygyno.2004.03.013.

[77] Q. Qi, Y. Ling, M. Zhu, L. Zhou, M. Wan, Y. Bao, Y. Liu, Promoter region methylation and loss of protein expression of PTEN and significance in cervical cancer, Biomed. Rep. 2 (2014) 653-658, doi:http://dx.doi.org/ 10.3892/br.2014.298.

[78] H.-J. Yang, V.W.S. Liu, Y. Wang, P.C.K. Tsang, H.Y.S. Ngan, Differential DNA methylation profiles in gynecological cancers and correlation with clinicopathological data, BMC Cancer 6 (2006) 212, doi:http://dx.doi.org/10.1186/ 1471-2407-6-212.

[79] M.G. Eijsink, M. a ten Hoor, H. Kok, H.W. de Bock, E. Nijman, G.B. a Wisman, A. G.J. van der Zee, The epidermal growth factor receptor pathway in relation to pelvic lymph node metastasis and survival in early-stage cervical cancer, Hum. Pathol. 41 (2010) 1735-1741, doi:http://dx.doi.org/10.1016/j. humpath.2010.04.017.

[80] Y. Harima, S. Sawada, K. Nagata, M. Sougawa, V. Ostapenko, T. Ohnishi, Mutation of the PTEN gene in advanced cervical cancer correlated with tumor progression and poor outcome after radiotherapy, Int. J. Oncol. 18 (2001) $493-497$.

[81] M.M.A. Rizvi, M.S. Alam, A. Ali, S.J. Mehdi, S. Batra, a K. Mandal, Aberrant promoter methylation and inactivation of PTEN gene in cervical carcinoma from Indian population, J. Cancer Res. Clin. Oncol. 137 (2011) 1255-1262, doi: http://dx.doi.org/10.1007/s00432-011-0994-0.

[82] A. Psyrri, R.A. Defilippis, A.P.B. Edwards, K.E. Yates, L. Manuelidis, D. Dimaio, Role of the retinoblastoma pathway in renescence triggered by repression of the human papillomavirus E7 protein in cervical carcinoma cells, Cancer Res. 64 (2004) 3079-3086.

[83] N. Wang, S. Wang, Q. Zhang, Y. Lu, H. Wei, W. Li, S. Zhang, D. Yin, Y. Ou, Association of p21 SNPs and risk of cervical cancer among Chinese women, BMC Cancer 12 (2012) 589, doi:http://dx.doi.org/10.1186/1471-2407-12-589.

[84] Y. Ma, Y. Zhang, L. Lin, X. Guo, Quantitative assessment of the relationship between p21 Ser31Arg polymorphism and cervical cancer, Tumor Biol. 34 (2013) 3887-3892, doi:http://dx.doi.org/10.1007/s13277-013-0976-8.

[85] S.L. Vargas-torres, E.A. Portari, A.L. Silva, Roles of CDKN1A gene polymorphisms (rs1801270 and rs1059234) in the development of cervical neoplasia, Tumor Biol. 37 (2016) 10469-10478, doi:http://dx.doi.org/ $10.1007 / \mathrm{s} 13277-016-4850-3$. 
[86] K. Ishida, A. Araki, An evaluation of the diagnostic and prognostic significance immunostaining in squamous intraepithelial lesions of the uterine cervix using liquid-based cytology specimens, Diagn. Cytopathol. 42 (2013) 125133, doi:http://dx.doi.org/10.1002/dc.

[87] Y. Zhang, L. Guo, P. Xing, Y. Chen, F. Li, W. Zhu, X. Lu, Increased expression of oncogene-induced senescence markers during cervical squamous cell cancer development, Int. J. Clin. Exp. Pathol. 7 (2014) 8911-8916.

[88] S.S. Liu, K. Chan, A.N. Cheung, X. Liao, T. Leung, H. Ngan, Expression of \#Np73 and TAp73 an independently associated with radiosensitivities and prognoses in cervical squamous cell carcinoma, Clin. Cancer Res. 73 (2006) 3922-3927, doi:http://dx.doi.org/10.1158/1078-0432 (CCR-05-2573).

[89] F.E. Henken, S.M. Wilting, R.M. Overmeer, J.G.I. van Rietschoten, a O.H. Nygren, A. Errami, J.P. Schouten, Meijer C.J.L.M, P.J.F. Snijders, R.D.M. Steenbergen, Sequential gene promoter methylation during HPV-induced cervical carcinogenesis, Br. J. Cancer 97 (2007) 1457-1464, doi:http://dx.doi. org/10.1038/sj.bjc.6604055.

[90] S.S. Wang, M.C. Bratti, A.C. Rodríguez, R. Herrero, R.D. Burk, C. Porras, P. González, M.E. Sherman, Z.E. Lan, M. Schiffman, S.J. Chanock, Common variants in immune and DNA Rrepair genes and risk for human papillomavirus persistence and progression to cervical cancer, J. Infect. Dis. 199 (2009) 20-30, doi:http://dx.doi.org/10.1086/595563 (Common.).

[91] S.S. Liu, R.C. Leung, K.Y. Chan, P. Chiu, A.N. Cheung, K. Tam, T. Ng, L. Wong, H.Y. Ngan, p73 expression is associated with the cellular radiosensitivity in cervical cancer after radiotherapy, Clin. Cancer Res. 10 (2004) 3309-3316.

[92] A.R. Ellison, J. Lofing, G.A. Bitter, Human MutL homolog (MLH1) function in DNA mismatch repair: a prospective screen for missense mutations in the ATPase domain, Nucleic Acids Res. 32 (2004) 5321-5338, doi:http://dx.doi org/10.1093/nar/gkh855.

[93] S. Sood, F.D. Patel, S. Ghosh, A. Arora, L.K. Dhaliwal, R. Srinivasan, Epigenetic alteration by DNA methylation of ESR1, MYOD1 and hTERT gene promoters is useful for prediction of response in patients of locally advanced invasive cervical carcinoma treated by chemoradiation, Clin. Oncol. (R. Coll. Radiol.) 27 (2015) 720-727, doi:http://dx.doi.org/10.1016/j.clon.2015.08.001.

[94] A. Spathis, E. Aga, M. Alepaki, A. Chranioti, C. Meristoudis, I. Panayiotides, D. Kassanos, P. Karakitsos, Promoter methylation of p16(INK4A), hMLH1, and MGMT in liquid-based cervical cytology samples compared with clinicopathological findings and HPV presence, Infect. Dis. Obstet. Gynecol. 2011 (2011) 927861, doi:http://dx.doi.org/10.1155/2011/927861.

[95] E. Giarnieri, R. Mancini, T. Pisani, M. Alderisio, A. Vecchione, Mlh1 Msh2, p53 Fhit, Bcl-2, and bax expression in invasive and in situ squamous cell carcinoma of the uterine cervix 1, Clin. Cancer Res. 6 (2000) 3600-3606.

[96] A. Ciavattini, M. Piccioni, A. Luigi Tranquilli, A. Filosa, T. Pieramici, G. Goteri, Immunohistochemical expression of DNA mismatch repair (MMR) system proteins (hMLH1, hMSH2) in cervical preinvasive and invasive lesions, Pathol. Res. Pract. 201 (2005) 21-25, doi:http://dx.doi.org/10.1016/j. prp.2004.09.012.

[97] S. Yoshiki, R. Matsunaga-Udagawa, K. Aoki, Y. Kamioka, E. Kiyokawa, M. Matsuda, Ras and calcium signaling pathways converge at Raf1 via the Shoc2 scaffold protein, Mol. Biol. Cell. 21 (2010) 1088-1096, doi:http://dx.doi.org/ $10.1091 / \mathrm{mbc}$. E09.

[98] V. Senchenko, J. Liu, E. Braga, N. Mazurenko, W. Loginov, Y. Seryogin, I. Bazov, A. Protopopov, F.L. Kisseljov, V. Kashuba, M.I. Lerman, G. Klein, E.R. Zabarovsky, Deletion mapping using quantitative real-time PCR identifies two distinct 3p21.3 regions affected in most cervical carcinomas, Oncogene 22 (2003) 2984-2992, doi:http://dx.doi.org/10.1038/sj.onc.1206429.

[99] S. Mitra, D.M. Indra, P.S. Basu, R.K. Mondal, A. Roy, S. Roychoudhury, C.K. Panda, Alterations of RASSF1A in premalignant cervical lesions: clinical and prognostic significance, Mol. Carconigenes 51 (2012) 723-733, doi:http://dx. doi.org/10.1002/mc.20837.

[100] J.P. Williams, T. Stewart, B. Li, R. Mulloy, D. Dimova, M. Classon, The retinoblastoma protein is required for Ras-induced oncogenic transformation, Mol. Cell. Biol. 26 (2006) 1170-1182.

[101] J. Campisi, F. d'Adda di Fagagna, Cellular senescence: when bad things happen to good cells, Nat. Rev. Mol. Cell Biol. 8 (2007) 729-740, doi:http://dx. doi.org/10.1038/nrm2233.
[102] S. Jagadeesh, P.P. Banerjee, Inositol hexaphosphate represses telomerase activity and translocates TERT from the nucleus in mouse and human prostate cancer cells via the deactivation of Akt and PKC $\alpha$, Biochem. Biophys. Res. Commun. 349 (2006) 1361-1367, doi:http://dx.doi.org/10.1016/j. bbrc.2006.09.002.

[103] K. Van Doorslaer, R.D. Burk, Association between hTERT activation by HPV E6 proteins and oncogenic risk, Virology 433 (2012) 216-219, doi:http://dx.doi. org/10.1016/j.virol.2012.08.006

[104] H.-Y. Wang, S. Park, S. Kim, D. Lee, G. Kim, Y. Kim, K.H. Park, H. Lee, Use of hTERT and HPV E6/E7 mRNA RT-qPCR TaqMan assays in combination for diagnosing high-grade cervical lesions and malignant tumors, Am. J. Clin. Pathol. 143 (2015) 344-351. (Accessed 21 January 2016) http://ajcp. oxfordjournals.org/content/ajcpath/143/3/344.full.pdf.

[105] F. Li, J. Cui, Human telomerase reverse transcriptase regulates vascular endothelial growth factor expression via human papillomavirus oncogene E7 in HPV-18-positive cervical cancer cells, Med. Oncol. 32 (2015) 199, doi http://dx.doi.org/10.1007/s12032-015-0649-0.

[106] Y. Shi, O. Zhao, L. Zhang, W.E.I. Du, Knockdown of hTERT by siRNA inhibits cervical cancer cell growth in vitro and in vivo, Int. J. Oncol. 45 (2014) 12161224, doi:http://dx.doi.org/10.3892/ijo.2014.2493.

[107] N. Vasiljevic, D. Scibior-bentkowska, A.R. Brentnall, J. Cuzick, A.T. Lorincz, Gynecologic Oncology Credentialing of DNA methylation assays for human genes as diagnostic biomarkers of cervical intraepithelial neoplasia in highrisk HPV positive women, Gynecol. Oncol. 132 (2014) 709-714, doi:http://dx. doi.org/10.1016/j.ygyno.2014.02.001.

[108] N. Milutin, I. Sabol, P. Planini, G. Grubi, I. Fistoni, Methylated host cell gene promoters and human papillomavirus type 16 and 18 predicting cervical lesions and cancer, PLoS One 10 (2015) e0129452, doi:http://dx.doi.org/ 10.1371/journal.pone.0129452.

[109] V. Vinothkumar, G. Arunkumar, S. Revathidevi, K. Arun, M. Manikandan, A. Kuha, D. Magendhra, K.S. Rajkumar, C. Ajay, R. Rajaraman, R. Ramani, A.K. Murugan, A.K. Munirajan, TERT promoter hot spot mutations are frequent in Indian cervical and oral squamous cell carcinomas, Tumor Biol. 37 (2016) 7907-7913, doi:http://dx.doi.org/10.1007/s13277-015-4694-2.

[110] B.T. Macdonald, K. Tamai, X. He, Review Wnt/b -Catenin signaling: components, mechanisms, and diseases, Dev. Cell. 17 (2009) 9-26, doi: http://dx.doi.org/10.1016/j.devcel.2009.06.016.

[111] I. Ramachandran, E. Thavathiru, S. Ramalingam, G. Natarajan, W.K. Mills, D.M. Benbrook, R. Zuna, S. Lightfoot, A. Reis, S. Anant, L. Queimado, Wnt inhibitory factor 1 induces apoptosis and inhibits cervical cancer growth, invasion and angiogenesis in vivo, Oncogene 31 (2011) 2725-2737, doi:http://dx.doi.org/ 10.1038/onc.2011.455

[112] W.F. van der Meide, S. Snellenberg, Meijer C.J.L.M, A. Baalbergen, T.J.M. Helmerhorst, W.B. van der Sluis, P.J.F. Snijders, R.D.M. Steenbergen, Promoter methylation analysis of WNT/ $\beta$-catenin signaling pathway regulators to detect adenocarcinoma or its precursor lesion of the cervix, Gynecol. Oncol. 123 (2011) 116-122, doi:http://dx.doi.org/10.1016/j.ygyno.2011.06.015.

[113] I. Näthke, Cytoskeleton out of the cupboard: colon cancer and cytoskeletal changes induced by loss of APC, Nat. Rev. Cancer 6 (2006) 967-974.

[114] J.M. Kooter, S.M. Wilting, C.J.L.M. Meijer, W. Quint, D.M. Sch, P.J.F. Snijders, R. D.M. Steenbergen, Longitudinal assessment of DNA methylation changes during HPVE6E7-induced immortalization of primary keratinocytes, Epigenetics 10 (2015) 73-81.

[115] S.M. Dong, H. Kim, S. Rha, Promoter hypermethylation of multiple genes in carcinoma of the uterine cervix, Clin. Cancer Res. 7 (2001) 1982-1986.

[116] P.O. Jawanjal, S.U. Salhan, I.N. Dhawan, R.I. Tripathi, G.A. Rath, Peptidyl-proly] isomerase Pin1-mediated abrogation of APC $-\beta$-catenin interaction in squamous cell carcinoma of cervix, Rom. J. Morphol. Embryol. 55 (2014) 8390.

[117] Y. Song, C. Zhang, Hydralazine inhibits human cervical cancer cell growth in vitro in association with APC demethylation and re-expression, Cancer Chemother. Pharmacol. 63 (2009) 605-613. 